\title{
Determinants of the voluntary adoption of digital reporting by small private companies to Companies House: Evidence from the UK
}

\begin{abstract}
This study examines the factors that influence the voluntary adoption of the digital reporting of the statutory accounts and returns to the company registry (Companies House) by small private companies in the UK. We analyse survey data from 343 members of the Association of Chartered Certified Accountants working in small companies or in practices with small company clients in the UK. The data is examined using statistical methods, mainly PLS-SEM. Our results show the following factors positively influence the voluntary adoption of digital reporting by small private companies: the relative advantage from standardisation benefits, the company's technology competence and support from top management. We also provide evidence that the complexity of the company's accounting system and technology costs inversely influence this voluntary adoption. The study contributes to the emerging literature by expanding our understanding of how the standardisation of financial information flows benefits small private companies. The results should be of interest to small companies and their accountants, regulators in the UK and other jurisdictions planning digital reporting initiatives or seeking to reduce administrative burdens on smaller entities.
\end{abstract}

\section{Keywords}

Companies House, small private companies, UK, voluntary digital reporting, XBRL/iXBRL 


\section{Introduction}

This study examines the factors that influence the voluntary adoption of digital reporting of statutory financial information to the company registry (Companies House) by small private companies in the UK. It also investigates whether such companies obtain benefits from the standardisation of their own financial information flows and/or other companies' digital data available at Companies House. While we know that large companies yield standardisation benefits, for example by having enterprise level IT budgets instead of autonomous IT budgets for each business unit (Weitzel et al., 2006; O’Riain et al., 2012; Valentinetti and Rea, 2012), evidence of the actual benefits of the standardisation of small private companies' financial information flows remains undocumented. This is because such standardisation in small private companies is in its infancy and was only introduced recently in the UK.

Small private companies play an important role in the UK economy. At the start of 2018, there were $1.91 \mathrm{~m}$ companies and corporations in the private sector and more than $99 \%$ were private limited companies. Among those private limited companies, 98\% were small, and yet they accounted for 34\% of jobs and 32\% of turnover (BEIS, 2018, Table 3). At the time of the study, a reporting entity qualified as small under the Companies Act 2006 if it was non-publicly accountable and (apart from a newly incorporated entity) met any two of the three size tests in the financial year concerned and the preceding year: annual turnover $£ 6.5 \mathrm{~m}$; balance sheet total $£ 3.26 \mathrm{~m}$; average number of employees 50 (Companies House, 2015).

Since 2005, the UK government has implemented two digital reporting initiatives for smaller entities. The first was to allow voluntary digital reporting to Companies House in order to reduce costs and relieve administrative burdens on small private companies, whilst improving the performance of the administrative and data processing tasks of this government agency (KPMG, 2006). Drawing on the literature (ICAEW, 2004; Companies House, 2013a; Collis et al., 2018), we define digital reporting as the filing of statutory accounts and returns at Companies House using a digital format.

The second initiative involved the provision of digital company search and data services by Companies House with a view to improving the accessibility of the data (Companies House, 2013b). Since April 2010, companies have been required to use inline eXtensible Business Reporting Language (iXBRL) for filing their corporate tax returns to HM Revenue and Customs (HMRC) (Collis et al., 2018). It was estimated that moving from paper to digital reporting would save £60m for Companies House and HMRC as well addressing the problem of different 
submission deadlines, duplicated information and the time-consuming and error-prone manual processes associated with paper filing (BIS, 2009). It was suggested that UK businesses would save between $£ 16 \mathrm{~m}$ and $£ 20 \mathrm{~m}$, with the additional benefits arising from improvements in the accuracy and reliability of the information supplied (KPMG, 2006). By 2015, Companies House had received information digitally for more than $85 \%$ of the accounts and returns online (Companies House, 2015).

Digital reporting is underpinned by XBRL, which is an open standard for creating, exchanging and analysing business information over the Internet (Eierle et al., 2014). The number of Standard Business Reporting (SBR) implementation projects based on XBRL is growing rapidly. For example, such initiatives have been successfully launched in the Netherlands (Cohen et al., 2014), Australia, Finland, China, Brazil, Belgium, New Zealand, India and Singapore (Ojala et al., 2018). XBRL allows companies to file one set of information instead of filing it repeatedly in different forms to different government agencies for different purposes (Sinnett and Willis, 2009). It requires the creation of a taxonomy that provides standardised information descriptions and formats, and allows the data to be tagged (Dhole et al., 2015). This drives out duplicated data and unnecessary descriptions (Eierle et al., 2014). In 2010, inline XBRL (iXBRL) was developed in the UK to absorb large amounts of information (HMRC, 2011). While XBRL can be used to present financial information in machine readable format, iXBRL presents it in both machine readable and human readable formats (Cohen et al., 2014). This allows the company's information to be presented in a normal document format, but with XBRL tags embedded in the soft copy document (Eierle et al., 2014).

The literature shows that considerable attention has been paid to extending our understanding of digital reporting in XBRL format, but most previous studies have focused on listed companies or government agencies as early adopters (e.g., Doolin and Troshani, 2007; Mousa, 2013). There is some evidence on the development of XBRL technology in the Netherlands (Robb et al., 2014) and Finland (Eierle et al., 2014), but the factors that drive adoption often differ across countries since national taxonomies reflect national regulatory frameworks (Deshmukh, 2004).

Although previous studies provide some evidence of the costs and benefits of XBRL reporting (e.g., Pinsker and Li, 2008; Premuroso and Bhattacharya, 2008; Dunne et al., 2009), they are either too small to permit generalisation or were conducted before digital reporting to HMRC became mandatory in the UK. The latter limitation means that a number of academic and 
practitioner-based studies (e.g., Lymer et al., 1999; 2012; Bonson et al., 2009; Troshani et al., 2015) are only able to discuss the potential benefits of digital reporting. Therefore, there is a need to obtain a better understanding of the actual benefits of digital reporting by investigating the experiences of filers and users.

This study examines the factors that determine the voluntary adoption of digital reporting by small private companies using the diffusion of innovation theory (Rogers, 1995) and the technology-organisation-environment framework (Tornatzky and Fleischer, 1990). It also examines the relative advantage of digitisation for the company by investigating two types of standardisation benefit: those that relate to the production of the financial information flows from companies (filers) to Companies House; and also the use of other companies' XBRL/iXBRL data filed at Companies House. The benefits of XBRL/iXBRL data have been described by Guilloux et al. (2013) in the context of the digital reporting battle between Electronic Data Interchange for Administration, Commerce and Transport (EDIFACT), which is standard set of syntax rules ratified by the United Nations, and XBRL in France. This identifies various benefits of XBRL. These include the readability between human and nonhuman actors, the potential to extend XBRL taxonomy to suit the needs of individual companies, and faster processing of information. In the present study, the examination of both the production of the digital financial information and use of other companies' digital data helps reveal the overall benefits to small private companies from the standardisation of information flows.

Our study addresses the following research question:

- What are the factors that influence the voluntary adoption of digital reporting by small private companies in the UK?

The remainder of the paper is structured as follows. First, we review the literature and develop our theoretical framework. Next, we describe our methods and the measures used in the analysis. We then report our results before drawing conclusions in the final section.

\section{Literature review and development of hypotheses}

\section{Diffusion of innovation theory}

A fundamental theory for the study of technology adoption is the diffusion of innovation theory (Rogers, 1995), which focuses on the characteristics of the innovation that affect the adoption 
of the technology (Zhu et al., 2006b). Diffusion is "the process in which an innovation is communicated through certain channels over time among the members of a social system" (Rogers, 2003, p. 5). The innovation characteristics include: relative advantage, compatibility, complexity, trialability, and observability (Picoto et al., 2014). A meta-analysis of 75 studies in the information systems literature (Tornatzky and Klein, 1982) identifies relative advantage, compatibility, complexity and the cost of technology as the main determinants of technology adoption which are be examined by this study.

According to Rogers (1983, p. 164) the innovation adoption process involves five stages: "First, knowledge occurs when an adopter is exposed to the innovation's existence and gains some understanding of how it functions. Second, persuasion occurs when an adopter forms a favourable or unfavourable attitude toward the innovation. Third, decision occurs when an adopter engages in activities that lead to a choice to adopt or reject the innovation. Fourth, implementation occurs when an adopter puts an innovation into use. Lastly, confirmation occurs when an adopter seeks reinforcement of an innovation-decision already made, but he or she may reverse this previous decision if exposed to conflicting messages about the innovation”. Dunne et al. (2013) focus on the first three stages (knowledge, persuasion and decision) in their study of the diffusion of XBRL to key stakeholder groups in the UK in 2009 before its implementation. They argue that unless stakeholders first understand XBRL, an investigation into its implementation is premature. The present study examines the third stage (decision) by focusing on the voluntary adoption of digital reporting to Companies House which became an option for small private companies at the time, whereas it had been mandatory at HMRC since 2011.

\section{The technology-organisation-environment framework}

Zhu et al. (2006b) argue that the diffusion of innovation theory needs to be enriched by adding variables representing specific contexts when the focus is on the complex technological innovations. Therefore, the present study employs the technology-organisation-environment framework proposed by Tornatzky and Fleischer (1990), which includes the following three contextual factors that affect the adoption of technology: “(1) technology context describes both the existing technologies in use and new technologies relevant to the firm; (2) organisation context refers to descriptive measures about the organisation such as scope, size, and the amount of slack resources available internally and (3) business environment context is the external 
arena in which a firm conducts its business - its industry, competitors, and dealings with government” (Tornatzky and Fleischer, 1990, p. 152-154).

Having reviewed the relevant literature, there are three reasons to build the model of the technology-organisation-environment framework. First, it is widely used and empirically tested for a variety of information technologies in the literature (e.g. Iacovou et al., 1995; Henderson et al., 2012; Dunne et al., 2013). This demonstrates its usefulness for understanding the diffusion of complex IS innovations. Second, the technology-organisation-environment framework and diffusion of innovation theory are consistent in that they focus on internal and external characteristics of the organisation as factors that drive the technology adoption. More specifically, the technology and organisation contexts are similar, but the technologyorganisation-environment framework includes a new context, the business environment (Zhu and Kaemer, 2005; Picoto et al., 2014). Consequently, it is important to combine them to obtain a comprehensive picture of the prominent factors in the study of new innovation (Wang et al., 2010; Henderson et al., 2012). Third, a theoretical model based on these two theories can be extended to include additional links which provide further understanding of the technology adoption (Chau and Tam, 1997; Thong, 1999). Other studies also find that the combined model will be better for understanding rather than employing one of them separately(e.g. Moore and Benbasat, 1991; Zhu et al., 2006c). Following this reasoning, we combine these two models in our theoretical model and focus on a set of variables that are the most common factors used by previous studies.

\section{Technology context}

Four factors are specified within the technology context which affect the voluntary adoption of digital reporting by small private companies: relative advantage, compatibility, complexity and costs (Tornatzky and Klein, 1982; Rogers, 1995). Relative advantage refers to "the degree to which an innovation is perceived as being better than the idea it supersedes” (Rogers, 1995, p. 213). Previous studies examine relative advantage by focusing on the expected benefits or perceived benefits from the technology adoption (e.g., Chwelos et al, 2001; Premuroso and Bhattacharya, 2008). Picoto et al. (2014) provide evidence that mobile-business has several unique characteristics that distinguish it from previous innovations such as portability, user identification, instant connectivity, and localization. Zhu et al (2006c) find that the expected benefits to a company area significant factor in the adoption of open-standard IOS. 
Digital reporting is based on open standards such as XBRL or iXBRL and numerous studies discuss the aggregate benefits of XBRL (e.g. Pinsker and Li, 2008; Vasarhelyi et al., 2010). Previous research suggests that XBRL offers several benefits to filers of financial information. Pinsker and $\mathrm{Li}$ (2008) provide evidence that digital reporting is faster than paper filing since all calculations are performed automatically. Other evidence (Dunne et al., 2009) indicates that $\mathrm{XBRL}$ is convenient for filing information to multiple government agencies since the accounts are submitted online instead of by post. Unlike paper filing, digital reporting eliminates manual errors arising from human intervention in the process (Roohani and Zheng, 2011) and this makes it more accurate (Vasarhelyi et al., 2012). According to Baldwin et al. (2006) and Alles and Piechocki (2012), digital reporting ensures better compliance with statutory requirements than paper filing because it facilitates real-time preparation of financial reports.

We add to prior literature by not only examining the benefits to the filers themselves, but also the benefits arising from their use of the XBRL/iXBRL data filed by other small private companies that is available from the Companies House website. The ultimate purpose of digital reporting in XBRL format is to enhance the quality and usefulness of financial information to users (Baldwin et al., 2006; Dhole et al., 2015). Several studies that have examined benefits of digital reporting via XBRL to users other than filers have consistently shown that XBRL speeds up the accessibility of information (Bonson et al., 2009), reduces the cost of acquiring digital information (Baldwin and Trinkle, 2011) and enhances the reuse of reports (Farewell and Pinsker, 2005). This is because the digital reports can be transmitted automatically from one system to another, without having to manually locate the information (Bartley et al., 2010).

There is also empirical evidence that digital data in XBRL format are more reliable than paper filing due to fewer filing errors resulted from automated process and elimination of human intervention (Dunne et al., 2009). Other evidence (Vasarhelyi et al., 2010) finds that digital reports are clear, understandable and comparable (Hodge et al., 2004) since the XBRL tags of each component of the accounts are based on a national taxonomy. They also find that the digital data improves analysis opportunities due to its amenability to the use of enhanced search engines (Hodge et al., 2004; Alles and Piechocki, 2012). Other studies report that digital reporting enhances the efficiency of business decisions (Henderson et al., 2012) and facilitates access to financial information on a continuous basis (Pinsker, 2003). We add to the prior literature by examining a large number of standardisation benefits to small private companies from their use of the structured data filed in XBRL/iXBRL format by other companies. This 
study takes a coherent approach by examining a range of benefits to small private companies and classified them into two types of standardisation benefits from digital reporting to small private companies' digital reporting and from the use of other companies' digital data at Companies House, which are positively associated with the adoption of technology. Based on the above discussion we postulate the first hypothesis.

H1: The relative advantage of digitisation positively influences the voluntary adoption of digital reporting by small private companies.

Compatibility is "the degree to which an innovation is consistent with existing business processes, practices and value systems” (Rogers, 2003, p. 212). There is evidence from information systems studies that the decision to adopt new technology is positively associated with its compatibility with the company’s current systems (e.g., Wang et al., 2010). Lack of compatibility could result in organisational resistance, which might delay e-business adoption (Zhu et al., 2006a). However, other studies (Huang et al., 2008; Picoto et al., 2014) suggest that this is not a significant problem since most Internet-based systems are already compatible with modern information systems. Previous research suggests that XBRL is more compatible with company's information system than PDF or Excel files, but companies should find an XBRL filing package that is compatible with its information systems (Dunne et al., 2009). However, companies that manage the XBRL filing process in-house may need to change their existing processes to accommodate the software (Lim and Perrin, 2014). We propose that compatibility of XBRL with company's information systems could make transferring data between different systems easier and thus reduce the need for substantial modification of the existing IT infrastructure. The above discussion leads to the following hypothesis:

H2: The compatibility of the company's accounting system with the filing software positively influences the voluntary adoption of digital reporting by small private companies.

Complexity is "the extent to which an innovation is perceived as a relatively difficult process to understand and use” (Rogers, 2003, p. 242). Previous studies suggest that complexity has a negative influence on the technology adoption decision (Zhu and Kraemer, 2005; Zhu et al., 2006b). A survey in the USA (Henderson et al., 2012) shows that companies that purchase commercial filing software to convert their financial reports into XBRL format are less likely to find the filing process a complex task. A study in Australia (Doolin and Troshani, 2007) suggests that the tagging process is problematic due to the specialist knowledge needed to tag 
financial data. This is supported by a study in the UK (Dunne et al., 2009) which reports that XBRL is complex and requires the time and effort to understand. This leads to our third hypothesis:

H3: The complexity of the filing process inversely influences the voluntary adoption of digital reporting by small private companies.

The costs of technology can be captured via a number of indicators: training costs, set-up costs, the cost of commercial technology software (Kuan and Chau, 2001; Zhu and Kaemer, 2005; Dunne et al., 2009). In a meta-analysis of 75 technology innovation studies, Tornatzky and Klein (1982) identify the costs of new technology as one of the factors that significantly influences a company's decision to use the technology. Zhu and Kaemer (2005) confirm that the cost of technology is negatively associated with the open-standard IOS adoption.

Lim and Perrin (2014) argue that the cost of purchasing of XBRL filing software, together with the training costs, could offset the benefits for early adopters. This supports earlier research in the UK by Dunne et al. (2009) who conclude that the cost of commercial filing software is one of the major obstacles to the use of XBRL as businesses do not have the internal resources to undertake the training necessary to adopt digital reporting. We suggest that the cost of commercial software to produce online documents, the set-up and/or running costs of digital reporting, and the training costs are high. Hence, our fourth hypothesis:

H4: The company's technology costs inversely influence the voluntary adoption of digital reporting by small private companies.

\section{Organisation context}

Two factors are specified within the organisation context that affect the voluntary adoption of digital reporting by small private companies: technology competence and management support.

Technology competence captures the internal technology resources available within a company to facilitate adoption of the new technology (Tornatzky and Fleischer, 1990). Some studies find that technology competence is positively associated with new technology adoption (e.g. Zhu et al., 2006b; Picoto et al., 2014). In this study, technology competence is captured by the company's use of e-applications, its IT infrastructure and its IT human resources. The use of eapplications refers to the company's experience of managing the technology (e.g. e-invoicing to customers, e-invoicing from suppliers, e-banking etc.). The IT infrastructure refers to the 
company's technical capability resulting from using the Internet and having specific technological tools to facilitate using digital reporting. The IT human resources refer to the skilled staff needed to use digital reporting software and related technologies.

A survey by Henderson et al. (2012) concludes the XBRL adoption requires both technical and accounting knowledge because the mapping process is complex and requires a company to choose the appropriate taxonomy and specific element in the taxonomy. Lim and Perrin (2014) confirm that the availability of technical expertise within a company can drive the company to using and understanding XBRL. Therefore, companies with the requisite expertise are more likely to adopt the innovation (Doolin and Troshani, 2007). Based on this argument, this study suggests that small companies with a higher level of technology competence will be more open to moving from paper reporting to digital reporting. This leads to our fifth hypothesis:

H5: The company's technological competence positively influences the voluntary adoption of digital reporting by small private companies.

Management support is a critical factor for innovation adoption in the context of e-commerce (Grandon and Pearson, 2004), Electronic Data Interchange (EDI) (Huang et al., 2008) and Enterprise resource planning (ERP) (Pan and Jang, 2008). Doolin and Troshani (2007) confirm that top management support for adopting XBRL is important for companies since it could significantly change the way business is conducted. Lim and Perrin (2014) argue that management is unlikely to support XBRL unless they have some knowledge about this innovation. Dunne et al. (2013) find that managers in the UK lack knowledge about the benefits and costs of XBRL technology.

In a small company it is particularly important to ensure there are adequate resources and an organisational champion to implement the innovation (Premkumar et al., 1997). Therefore, enthusiastic support for digital reporting by the principal director (often the owner-manager in a small company) and the allocation of adequate financial resources are essential to move from paper to digital reporting. If he/she is not convinced of the technology, it is very unlikely that it will be adopted. Accordingly, we propose the following hypothesis:

H6: Top management support positively influences the voluntary adoption of digital reporting by small private companies. 


\section{Business environment context}

Network effects within the business environment are considered to have an important influence on the adoption of new technology (Zhu et al., 2006c; Huang et al., 2008) and hence affect the voluntary adoption of digital reporting by small private companies. Network effects are defined as "the value of membership to one user [which] is positively affected when another user joins and enlarges the network" (Katz and Shapiro, 1994, p. 94). Once the number of users reaches a critical mass, the external benefit of technology adoption emerges and attracts more users to join (Lin and Bhattacherjee, 2008).

Doolin and Troshani (2007) find that XBRL adoption is heavily dependent on take-up by a critical mass of suppliers and competitors, which is lacking in Australia. Their interview evidence suggests that the benefits of XBRL increase as the use of the technology becomes more widespread. Once a critical mass is reached, the benefits to early adopters are apparent and this provides a strong incentive for others to use XBRL, thus increasing diffusion. As a type of an open standard technology, XBRL enjoys two significant network effects (Eierle et al., 2014): trading community influence (from a company's customers and suppliers) and peer influence (from the company's competitors), which are positively associated with the use of technology. In light of this argument, we postulate the following hypothesis:

H7: Network effects positively influence the voluntary adoption of digital reporting by private companies.

Figure 1 presents the theoretical model which incorporates the factors we have defined in this section. 


\section{Figure 1}

\section{The theoretical model}

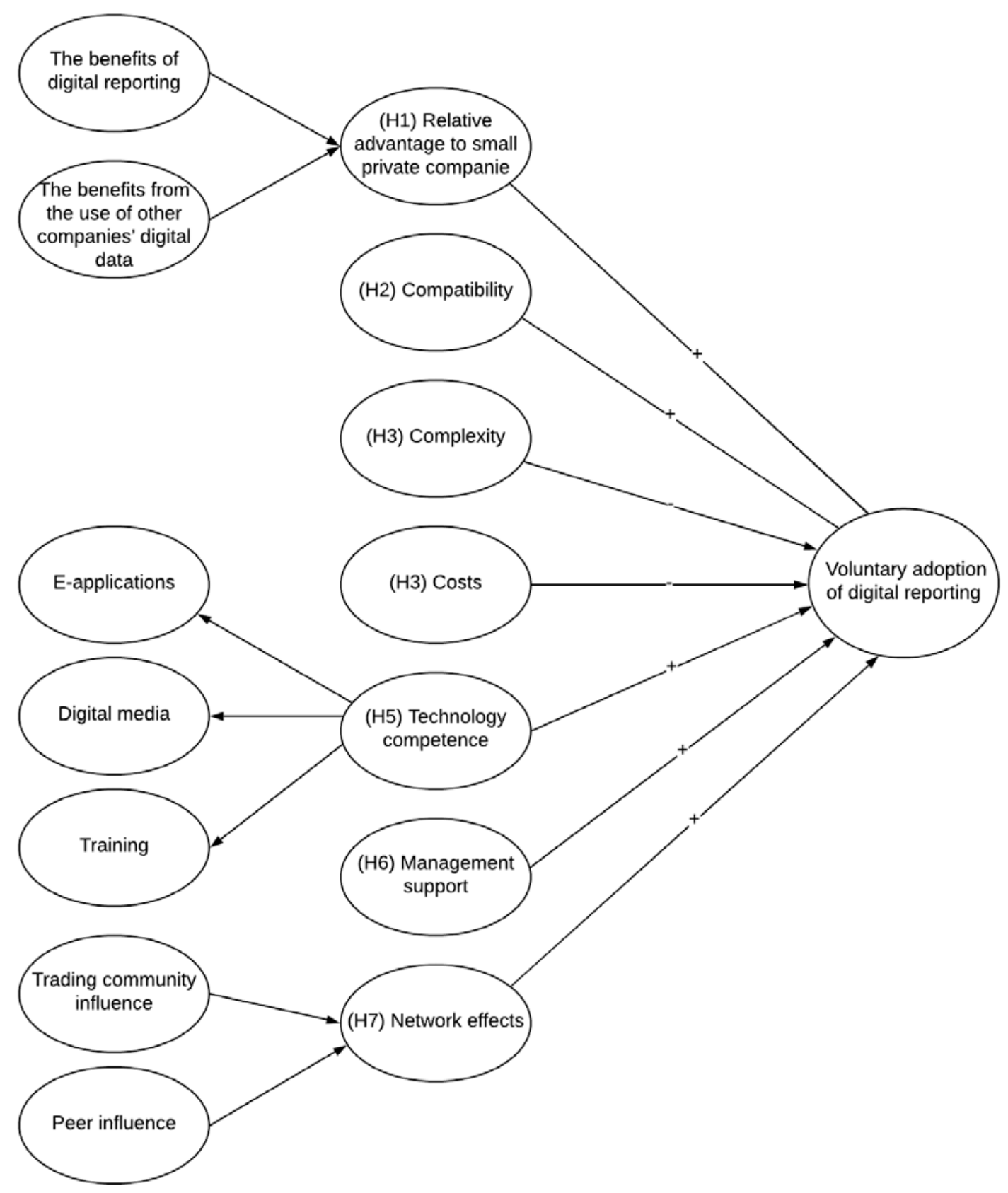




\section{Methods}

\section{Data}

The online questionnaire used to collect the data for the study was based on prior literature and interviews with 11 accountants. It was subjected to several checks and revisions by an expert panel to ensure content/face validity and was then piloted with five accountants.

The Association of Chartered Certified Accountants (ACCA) facilitated the dissemination of the questionnaire by sending an electronic invitation letter containing a hyperlink to the online survey to 19,972 of its UK members in November 2015. The invitation requested a response only from accountants working in a small private company or in an accountancy practice with at least one small private company client. The questionnaire instructed those in the latter group to think of one particular small company client when answering the questions and this allowed the unit of analysis to be a small private company. Reminders were sent to non-respondents three weeks after the initial request. Three unusable questionnaires were discarded, resulting in a final dataset of 343 valid questionnaires, which is sufficient for a robust multivariate analysis (Hoelter, 1983; Bollen, 1998; Henseler et al., 2014). Table 1 shows the key characteristics of the sample. 
Table 1

Key characteristics of the sample $(n=343)$

\begin{tabular}{|c|c|c|c|}
\hline Characteristic & Category & Frequency & Percent \\
\hline \multirow[t]{2}{*}{ Respondents } & $\begin{array}{l}\text { Accountant in practice with at least one small } \\
\text { company client }\end{array}$ & 241 & 70.3 \\
\hline & $\begin{array}{l}\text { Accountant working in a small private } \\
\text { company }\end{array}$ & 102 & 29.7 \\
\hline \multirow[t]{5}{*}{ Age of the respondent } & Up to 30 years & 28 & 8.2 \\
\hline & $31-40$ & 72 & 21.1 \\
\hline & $41-50$ & 92 & 27.0 \\
\hline & $51-60$ & 100 & 29.3 \\
\hline & More than 60 years & 49 & 14.4 \\
\hline \multirow{3}{*}{$\begin{array}{l}\text { Respondent's filing } \\
\text { experience }\end{array}$} & Both HMRC and Companies House & 309 & 90.1 \\
\hline & Companies House only & 22 & 6.4 \\
\hline & HMRC only & 12 & 3.5 \\
\hline \multirow{3}{*}{$\begin{array}{l}\text { Format for filing company } \\
\text { tax returns at HMRC }\end{array}$} & Online corporation tax returns & 315 & 91.8 \\
\hline & Paper corporation tax returns & 15 & 4.4 \\
\hline & No response & 13 & 3.8 \\
\hline \multirow{4}{*}{$\begin{array}{l}\text { Format for filing accounts } \\
\text { and returns at Companies } \\
\text { House }\end{array}$} & Online annual returns & 322 & 93.9 \\
\hline & Online statutory accounts & 299 & 87.2 \\
\hline & Paper statutory accounts & 66 & 19.2 \\
\hline & Paper annual returns & 9 & 2.6 \\
\hline
\end{tabular}

As can be seen in Table 1, most of the respondents (70\%) were accountants in practice with small company clients, and the remainder were accountants working in small private companies. This confirms evidence from the UK that the majority of smaller companies rely on an external accountant for help with financial reporting (Collis, 2012). The age of the respondents was well distributed, giving confidence that there was no bias towards the younger generation who might be more familiar with online applications. As the vast majority of respondents (90\%) file both the company's tax return to HMRC and the statutory accounts and returns at Companies House, this gives confidence that they have the appropriate experience to answer the survey questions.

Digital reporting of corporation tax returns to HMRC is compulsory for small private companies and Table 1 shows that nearly all (92\%) comply. However, there are some exceptions to this rule, which explain why we did not find $100 \%$ doing so. ${ }^{1}$ Although digital reporting to Companies House was voluntary for small companies at the time of the study,

\footnotetext{
${ }^{1}$ HMRC plans to move to a fully digital filing system by 2020 (HMRC, 2017). These changes started in 2018 with income tax for businesses, self-employed people and landlords with annual turnover above the VAT threshold. In 2019-20 the income tax elements will be extended to all businesses, self-employed people and landlords with annual turnover above £10,000, followed by VAT in 2019 and corporation tax in 2020.
} 
Table 1 shows that $94 \%$ of the respondents used online methods for filing the company's annual returns and $87 \%$ used online methods for filing the statutory accounts. This provides abundant evidence that the respondents had appropriate experience to answer the questionnaire.

Apart from peer influence, the constructs are multiple items and most of their indicators are measured using a five-point Likert scale. For the following indicators, the scale represents $5=$ Highest level of agreement, 3 neutral, and 1 = Highest level of disagreement. These indicators are DATATRANSFER, BURDEN, TRAINCOST, SOFTWARECOST, FUNDING, CHAMPIONING, TECHNICEXP, SPECIALTRAIN, SPEED, CONVENIENT, ACCURACY, REJECTION, COMPLIANCE, FASTERACCESS, LOWCOST, CLEAR, USABILITY, RELIABLE, UNDERSTANDABLE, COMPARABLE, MANIPULATABLE, EFFIECDECISION, CONTINACCESS and FAMILIARITY.

We measure CUSTOMERS, SUPPLIERS, COMPETITORS using a five-point Likert scale where 5 = Strongest level of influence and $1=$ No influence. However, ITMODIFYING, ACSTANDARDS, EFFORT, SIMPLICITY, SETUPCOST and CREDITDECISION are measured using a five-point Likert scale where 5 = Highest level of disagreement, 3 neutral, and 1 = Highest level of agreement. EAPPLICATIONS, DIGITALMEDIA, TRAINING, TAXRET, STATACS, ANNURET and DIGITALSERV are dichotomous variables $(1=$ Yes, $0=$ Otherwise). The constructs and associated indicators in the measurement model are presented in Appendices A and B.

Table 2 presents descriptive statistics for the ordinal variables in the analysis. As can be seen, the results of the Mann-Whitney test to examine differences between the first and second responders to the survey questionnaire show that non-response bias was not a problem. This, together with the size of the sample gives confidence that the results of our study can be generalised to other UK accountants working in or providing services to small private companies. Since we combine the responses from the accountants in business and accountants in practice, we also assessed the common method bias using Harman's one factor test (Podsakoff et al., 2003), which found no difference between the two groups, with two exceptions: cost and complexity. A plausible explanation for the difference in terms of cost could be that an accountant in business perceives the cost of the technology to be relatively high because the business must bear the entire cost of any commercial filing software bought, whereas an accountant in practice can spread the cost across a number of clients. Furthermore, 
the accountant in business only files one company's accounts and returns, whereas an accountant in practice becomes very adept if he or she files the accounts and returns for several clients each year. This may also explain the difference between the two groups in terms of complexity. To test for potential response bias due to respondents' positions, we split the full sample into two groups: Accountants in practice and accountants working in small private companies. We run a PLS-SEM multigroup analysis (PLS-MGA) to find out whether there is a significant difference between path coefficients of the two groups in the structural model following the guidelines by Hair et al. (2014). Descriptive statistics and PLS-MGA results are shown in Table 2. The $p$-value of the PLS-MGA for each construct is insignificant, which suggests that respondent's positions did not result in serious biases in our dataset. 
Table 2

Descriptive statistics: Ordinal variables

\begin{tabular}{|c|c|c|c|c|c|c|c|c|c|c|c|c|}
\hline \multirow[t]{2}{*}{ Constructs } & \multicolumn{3}{|c|}{$\begin{array}{l}\text { Full sample } \\
(\mathrm{n}=343)\end{array}$} & \multicolumn{3}{|c|}{$\begin{array}{l}\text { Accountants in business } \\
\qquad(\mathrm{n}=102)\end{array}$} & \multicolumn{3}{|c|}{$\begin{array}{l}\text { Accountants in practice } \\
\qquad(\mathrm{n}=241)\end{array}$} & \multicolumn{2}{|c|}{$\begin{array}{c}\text { Mann-Whitney } U \\
\text { test }\end{array}$} & \multirow{2}{*}{$\begin{array}{c}\text { PLS-MGA } \\
P \text {-value }\end{array}$} \\
\hline & Mean & Median & Std. dev. & Mean & Median & Std. dev. & Mean & Median & Std. dev. & $\begin{array}{l}\text { Z- } \\
\text { Score }\end{array}$ & P-value & \\
\hline Relative advantage & 3.59 & 3.75 & 1.016 & 3.51 & 3.75 & 1.158 & 3.64 & 3.75 & 0.933 & 0.218 & 0.848 & 0.622 \\
\hline Compatibility & 3.57 & 3.50 & 0.945 & 3.56 & 3.50 & 0.895 & 3.57 & 3.50 & 0.968 & -0.201 & 0.841 & 0.263 \\
\hline Complexity & 2.76 & 3.00 & 0.895 & 2.94 & 3.00 & 0.729 & 2.68 & 2.50 & 0.947 & -2.766 & 0.006 & 0.912 \\
\hline Cost & 3.34 & 3.50 & 0.945 & 3.05 & 3.00 & 0.979 & 3.46 & 3.50 & 0.905 & -3.556 & 0.000 & 0.269 \\
\hline Management support & 4.00 & 4.00 & 0.870 & 3.90 & 4.00 & 0.853 & 4.04 & 4.00 & 0.875 & -1.631 & 0.103 & 0.999 \\
\hline Network effects & 2.18 & 2.00 & 0.966 & 2.20 & 2.33 & 0.980 & 2.18 & 2.00 & 0.963 & -0.247 & 0.805 & 0.361 \\
\hline Trading community influence & 2.21 & 2.00 & 1.032 & 2.16 & 2.00 & 1.042 & 2.22 & 2.00 & 1.030 & -0.535 & 0.592 & 0.595 \\
\hline Peer influence & 2.14 & 2.00 & 1.158 & 2.27 & 2.00 & 1.145 & 2.08 & 2.00 & 1.161 & -1.593 & 0.111 & 0.118 \\
\hline Digital reporting benefits & 3.95 & 4.00 & 0.719 & 3.99 & 4.00 & 0.635 & 3.94 & 4.00 & 0.752 & -0.308 & 0.758 & 0.776 \\
\hline $\begin{array}{l}\text { Benefits from the use of other } \\
\text { companies' digital data }\end{array}$ & 3.24 & 3.50 & 1.313 & 3.02 & 3.50 & 1.681 & 3.33 & 3.50 & 1.114 & -0.128 & 0.898 & 0.159 \\
\hline
\end{tabular}

Note: All items measured on a 5-point Likert scale. 


\section{Constructs}

The questionnaire used to collect the data for this study was developed according to the guidelines provided by Straub (1989) and Hinkin (1998). The first step involves operationalising the hypothetical constructs by identifying indicators which can be measured empirically. We adopted the operational definitions of the constructs identified by prior information systems studies and the XBRL literature in particular (e.g., Zhu and Kraemer, 2005; Zhu et al., 2006a), with minor changes to suit digital reporting by small private companies as shown in Appendix A and Appendix B. To ensure the content/face validity of the hypothetical constructs and the questionnaire as a whole, we conducted preliminary interviews with 11 accountants and a panel of experts to obtain feedback. The final draft of the questionnaire was then piloted with five accountants.

Three constructs and their indicators were specifically designed for the study because they are new or had not been measured adequately in previous studies: the voluntary adoption of digital reporting; digital reporting benefits to small private companies; and benefits to small private companies from the use of other companies' digital data. Prior research suggests that digital reporting in XBRL is a technology that consists of several elements (e.g., Henderson et al., 2012). Therefore, companies can partially or fully adopt digital reporting. A small company can choose to use XBRL/iXBRL for filing their statutory returns and/or accounts at Companies House in the UK (Premuroso and Bhattacharya, 2008).

Three constructs require further explanation and these are presented in Appendices A and B. The first construct is relative advantage. This is modelled as a second-order construct and measured by (a) the benefits of digital reporting to small private companies and (b) the benefits to small private companies from the use of other companies' digital data. We followed the approach suggested by Chin and Gopal (1995, p.49) by treating the factors underlying relative advantage as multidimensional entities of a higher-order construct or second-order construct. The second construct that requires further explanation is technology competence. This is modelled as a second-order reflective construct and can be measured by first-order construct(s) or dimensions derived from the prior literature and validated from interview findings (Wright et al., 2012; Hair et al., 2016). This is operationalised by three dimensions: the use of eapplications by the small company and the extent to which familiarity with e-applications has encouraged the company to use digital reporting; the digital reporting medium used by the small 
company to submit the returns and accounts online at Companies House; and the IT skills and training required to use digital reporting. The third construct that requires explanation is network effects. This is modelled as a second-order construct and operationalised by two dimensions: trading community influence and peer influence (Zhu et al., 2005c). Stewar and Segars (2002) suggest that a second-order approach represents a theoretically strong basis for capturing complex measures

According to Henseler et al. (2009) and Hair et al. (2016), the loading of indicator should be 0.708 or above, although 0.70 is acceptable. ${ }^{2}$ Another consideration when deciding whether to delete the indicator is the extent to which its removal affects the internal consistency and convergent validity of the underlying construct. We initially assess the relevance of reflective indicators. We also examine the effect of indicator removal before evaluating the measurement and structural model. Table 3 shows the results of the initial assessment of the indicators. We also use exploratory factory analysis to test the robustness of the measurement model (not tabulated). Principal component analysis with Equamax and Varimax rotations suggests that all indicators are loaded into their hypothetical constructs based on the literature.

\section{Table 3}

\section{Initial model assessment}

\begin{tabular}{|c|c|c|c|}
\hline Indicator & Loading & Criteria & Decision \\
\hline TRAINCOST $^{R}$ & 0.083 & $(<0.40)$ & Deleted \\
\hline DATATRANSFER & 0.549 & $(>0.40$ but $<0.70)$ & Deleted \\
\hline ITMODIFYING ${ }^{R}$ & 0.651 & $(>0.40$ but $<0.70)$ & Retained \\
\hline SIMPLICITY ${ }^{R}$ & 0.254 & $(<0.40)$ & Deleted \\
\hline$E F F O R T^{R}$ & 0.601 & $(>0.40$ but $<0.70)$ & Retained \\
\hline TECHNICALEXPERT & 0.039 & $(<0.40)$ & Deleted \\
\hline SPECIALTRAIN & 0.008 & $(<0.40)$ & Deleted \\
\hline SPEED & 0.615 & $(>0.40$ but $<0.70)$ & Retained \\
\hline CONVENIENT & 0.602 & $(>0.40$ but $<0.70)$ & Retained \\
\hline REJECTION & 0.684 & $(>0.40$ but $<0.70)$ & Retained \\
\hline CREDITDECISION $^{R}$ & 0.117 & $(<0.40)$ & Deleted \\
\hline
\end{tabular}

${ }^{R}$ Reversed indicator

\footnotetext{
${ }^{2}$ The loading of the indicator refers to "the results of single regressions of each indicator on their corresponding construct" (Hair et al., 2016, p.92). The square of a standardized indicators loading, referred to as the communality of an item, represents how much of the variation in an item is explained by the construct. Therefore, the square of loading $\left(0.708^{2}\right)$ equals 0.50 (Hair et al., 2016, p.104)
} 


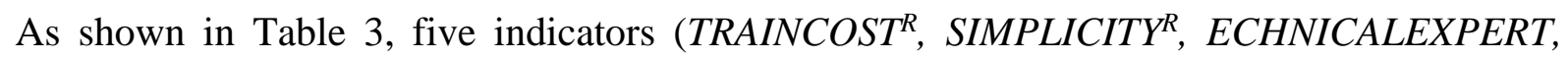
SPECIALTRAIN, and CREDITDECISION) are deleted as recommended by Henseler, Ringle and Sinkovics (2009) and Hair et al. (2016) because the loadings are very low $(<0.40)$. Since these relate to reflective constructs, their removal has no impact on our final results and the questionnaire maintains its conceptual integrity. A sixth indicator (DATATRANSFER) is removed because the value of convergent validity, as measured by the AVE and composite reliability in the underlying construct, is higher than 0.5 and 0.7 respectively after the deletion.

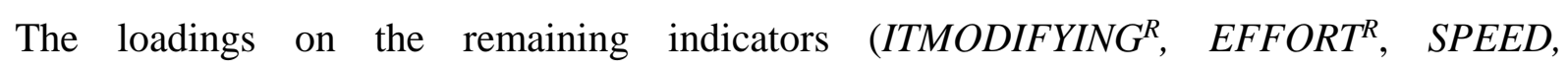
CONVENIENT and REJECTION) are retained in the final measurement model and the structural model evaluation as the AVE and composite reliability in their underlying constructs are within the suggested threshold values $(>0.40$ but $<0.70)$ without deletion.

\section{Analysis and results}

Multivariate analysis in the form of partial least squares structural equation modelling (PLSSEM) ${ }^{3}$ was used to analyse the survey data. We chose PLS-SEM for a number of reasons. It is a powerful multivariate technique for validating the model and testing the hypotheses (Zhu et al., 2006a, 2006c; Picoto et al., 2014). It is used extensively in information systems research (Gefen and Straub, 2005) and is recommended for theory development (Chin, 1998). Finally, it does not place a high requirement on the normal distribution of the source data (Gefen et al., 2011) and its components-based algorithms can handle both formative and reflective constructs (Gefen et al., 2011). As recommended by Gerbing and Anderson (1988), we conduct the analysis in two steps: the measurement model followed by the structural model.

\footnotetext{
${ }^{3}$ Aided by SmartPLS3 software.
} 


\section{Assessment of the measurement models}

Reflective measurement model

We follow Henseler et al. (2009) and Gefen et al. (2011) and assess the reflective measurement model in terms of the construct reliability, convergent validity and discriminant validity. We assess the construct reliability using composite reliability that measures the degree to which items are free from random error and therefore yield consistent results (Zhu and Kraemer, 2005). The composite reliability of the construct should be greater than 0.70 , but values of 0.60 to 0.70 are acceptable in exploratory research (Hair et al., 2016). As can be seen from Table 4, the results are satisfactory as the levels of composite reliability are above 0.60 for all reflective constructs.

\section{Table 4}

Composite reliability and convergent validity

\begin{tabular}{lcc}
\hline Reflective construct & $\begin{array}{c}\text { Composite } \\
\text { reliability }\end{array}$ & AVE \\
\hline Compatibility & 0.800 & 0.672 \\
Complexity & 0.658 & 0.500 \\
Costs & 0.756 & 0.602 \\
Management support & 0.728 & 0.669 \\
Technology competence & 0.700 & 0.730 \\
Voluntary adoption of digital reporting & 0.835 & 0.562 \\
\hline
\end{tabular}

We use two criteria for assessing convergent validity, which reflects the consistency across multiple operationalisation (Zhu and Kraemer, 2005). The first criterion states that the AVE should be above 0.5 (Hair et al., 2016). As shown in Table 4, apart from digital reporting benefits to small private companies, all constructs have AVE values above 0.5, indicating that each construct represents one dimension and explains more than a half the variance of its indicators (Henseler et al., 2009).

The second criterion refers to the indicator loadings reliability. A common rule of thumb is that each indicator loading should be 0.708 or above and all indicators loadings should be statistically significant (Hair et al., 2014). Table 5 presents the results of the test for convergent validity. Most of the estimated standard loadings are higher than 0.708 and statistically significant, apart from ITMODIFYING, EFFORT, E-APPLICATIONS, DIGITALMEDIA, 
TRAINING and STATACS. Although their loadings are less than 0.708, they are statistically significant and the AVE and composite reliability in their underlying constructs are higher than 0.5 and 0.7 respectively.

Table 5

Convergent validity: Indicator loadings

\begin{tabular}{llllll}
\hline Reflective construct & Indicator code & Mean & $\begin{array}{l}\text { Std. } \\
\text { dev. }\end{array}$ & Loadings & T Stat \\
\hline Compatibility & ITMODIFYING $^{R}$ & 3.417 & 1.167 & $0.680^{* * *}$ & 3.428 \\
& ACSTANDARDS $^{R}$ & 3.720 & 1.100 & $0.939^{* * *}$ & 8.168 \\
\hline Complexity & EFFORT $^{R}$ & 2.224 & 1.180 & $0.550^{* *}$ & 3.909 \\
& BURDEN & 3.292 & 1.341 & $0.836^{* * *}$ & 4.500 \\
\hline Costs & SETUPCOST & 2.878 & 1.341 & $0.742^{* * *}$ & 6.148 \\
& SOFTWCOST & 2.440 & 1.067 & $0.816^{* * *}$ & 6.946 \\
\hline Management & FUNDING & 3.953 & 0.983 & $0.702^{* * *}$ & 5.280 \\
support & CHAMPIONING & 4.044 & 1.104 & $0.969^{* * *}$ & 30.986 \\
\hline Technology & E-APPLICATIONS & 2.42 & 1.510 & $0.616^{* * * *}$ & 5.024 \\
competence & FAMILIARITYE-APPS & 3.023 & 1.609 & $0.890^{* * *}$ & 5.091 \\
& DIGITALMEDIA & 1.43 & 0.721 & $0.654^{* * *}$ & 7.057 \\
& TRAINING & 1.11 & 1.129 & $0.539^{* * *}$ & 4.135 \\
\hline Voluntary adoption & STATACS & 0.85 & 0.356 & $0.675^{* * *}$ & 10.196 \\
of digital reporting & ANNURET & 0.91 & 0.291 & $0.862^{* * *}$ & 29.492 \\
\hline
\end{tabular}

Notes: ${ }^{\mathrm{R}}$ indicates a reversed item. ${ }^{* * *} p<0.001 ;{ }^{* *} p<0.01 ;{ }^{*} p<0.05$

We used two criteria for assessing the discriminant validity, which is defined as the extent to which different constructs diverge from one another (Hair et al., 2014). The first criterion is the cross loadings of the indicators (Hair et al., 2011). All indicator loadings on the associated construct should be greater than its loadings on other constructs (i.e., the cross loadings). As shown in Appendix C, the first criterion is satisfied for all indicators and their constructs.

The second criterion used to assess the discriminant validity is the Fornell-Larcker condition that AVEs should be greater than the squared correlations and each indicator should have a higher correlation to the assigned latent variable than to any other latent variable (Picoto et al., 2014). It is a more conservative approach than cross loadings for assessing discriminant validity (Fornell and Larcker, 1981). The construct has good discriminant validity if the square root of the AVE of the multi-items' reflective constructs is greater than the absolute value of interconstruct correlations (Hair et al., 2016). As shown in Table 6, all reflective constructs meet this criterion and, therefore, the indicators share more common variance with their associated constructs than with other constructs. 


\section{Table 6}

Discriminant validity: Fornell-Larcker (AVE and correlations)

\begin{tabular}{|c|c|c|c|c|c|c|c|}
\hline & Construct & (1) & (2) & (3) & (4) & (5) & (6) \\
\hline (1) & Compatibility & 0.820 & & & & & \\
\hline (2) & Complexity & -0.170 & 0.707 & & & & \\
\hline (3) & Costs & -0.116 & 0.018 & 0.780 & & & \\
\hline (4) & Management support & 0.248 & -0.158 & -0.061 & 0.771 & & \\
\hline (5) & Technology competence & 0.088 & 0.080 & 0.008 & 0.308 & 0.608 & \\
\hline (6) & $\begin{array}{l}\text { Voluntary adoption of } \\
\text { digital reporting }\end{array}$ & 0.130 & -0.130 & 0.182 & 0.271 & 0.287 & 0.749 \\
\hline
\end{tabular}

Notes: The diagonal values in bold are the AVE square root and the off-diagonal values are the correlations.

\section{Formative measurement model}

We also examine the content validity, multicollinearity and the significance and sign of weights for the formative measurement model. The content validity was assessed by experts to evaluate the extent to which the indicators capture the major facets of the construct (Diamantopoulos et al., 2008). As shown in Table 7, the formative indicators for each construct are examined for collinearity using the variance inflation factor (VIF) (Hair et al., 2016). The relevance of each formative indicator is evaluated by comparing the weights of the indicators to determine their relative contribution to forming the construct (Hair et al., 2016). The significance of each indicator is evaluated using $t$-values, drawing on the standard error. Table 7 presents the VIF for the formative indicators which are all below the suggested cut-off value of 3.3 (Petter et al., 2007), giving confidence that multicollinearity is not a problem. The formative indicators' weights are above the suggested cut-off of 0.3 (Chin, 1998) and highly significant $(p<0.001)$. Overall, the formative constructs in the model are acceptable. 
Table 7

Formative constructs assessment

\begin{tabular}{|c|c|c|c|c|}
\hline Formative construct & Indicator code & VIF & Weight & t-value \\
\hline \multirow[t]{2}{*}{ Relative advantage } & DIGITALREPORTINGBENEFITS & 1.083 & 0.421 & 5.246 \\
\hline & $\begin{array}{l}\text { BENEFITSFROMTHEUSEOFOTH } \\
\text { ERSCOMPANIES'DIGITALDATE }\end{array}$ & 1.083 & 0.959 & 63.659 \\
\hline \multirow[t]{5}{*}{ Digital reporting benefits } & FASTERFILING & 2.223 & $0.655 * * *$ & 10.298 \\
\hline & CONVENIENT & 1.246 & $0.660 * * *$ & 10.037 \\
\hline & REJECTION & 1.173 & $0.593 * * *$ & 8.659 \\
\hline & ACCURACY & 1.281 & $0.681^{* * *}$ & 10.639 \\
\hline & BETTERCOMPLIANCE & 1.364 & $0.760 * * *$ & 18.369 \\
\hline \multirow{10}{*}{$\begin{array}{l}\text { Benefits from the use of } \\
\text { other companies' digital } \\
\text { data }\end{array}$} & FASTERACCESS & 1.912 & $0.839 * * *$ & 38.218 \\
\hline & LOWCOST & 2.032 & $0.832 * * *$ & 35.401 \\
\hline & CLEAR & & $0579 * * *$ & 8.261 \\
\hline & USABILITY & 1.931 & $0.631^{* * *}$ & 9.924 \\
\hline & RELIABLE & 1.469 & $0.857 * * *$ & 41.762 \\
\hline & UNDERSTANDABLE & 1.052 & $0.862 * * *$ & 51.786 \\
\hline & COMPARABLE & 1.582 & $0.910 * * *$ & 87.530 \\
\hline & MANIPULATABLE & 1.547 & $0.866^{* * *}$ & 62.029 \\
\hline & EFFICIENTDECISION & 1.634 & $0.876^{* * *}$ & 62.558 \\
\hline & CONTINOUSACCESS & 1.516 & $0.863^{* * *}$ & 45.977 \\
\hline \multirow[t]{2}{*}{ Network effects } & TRADINGPARTNER & 1.548 & $0.688^{* * *}$ & 38.225 \\
\hline & PEER & 1.548 & $0.424 * * *$ & 31.426 \\
\hline \multirow{2}{*}{$\begin{array}{l}\text { Trading community } \\
\text { influence }\end{array}$} & CUSTOMERS & 1.687 & $0.872 * * *$ & 95.160 \\
\hline & SUPPLIERS & 1.244 & $0.825 * * *$ & 33.807 \\
\hline Peer influence & COMPETITORS & 1.613 & $0.420^{* * *}$ & 39.324 \\
\hline
\end{tabular}

Note: ${ }^{* *} p<0.001 ;{ }^{* *} p<0.01 ;{ }^{*} p<0.05$

\section{Results of hypotheses testing}

Structural model

After establishing that the psychometric properties of the measurement model are satisfactory, the structural model was assessed. To estimate the significance of the paths in the PLS-SEM model, 5,000 bootstrap samples are generated as recommended by Henseler et al. (2009) and Hair et al. (2016). Our hypothesis testing is based on the examination of the standardized paths and the results are shown in parentheses in Figure 2. The pseudo $R^{2}$ indicates how well the exogenous constructs explain the endogenous constructs. The full model in Figure 2 explains $19.3 \%$ of the variance in the voluntary adoption of digital reporting to Companies House. The SmartPLS3 results show that the $R^{2}$ is highly significant $(p<0.001)$. According to Hair et al. (2016), it is difficult to provide a rule of thumb for acceptable $R^{2}$ values as this depends on the 
model complexity and the research discipline. However, they suggest that more paths pointing toward a target construct will produce a higher $R^{2}$.

\section{Figure 2}

PLS structural model results $(n=343)$

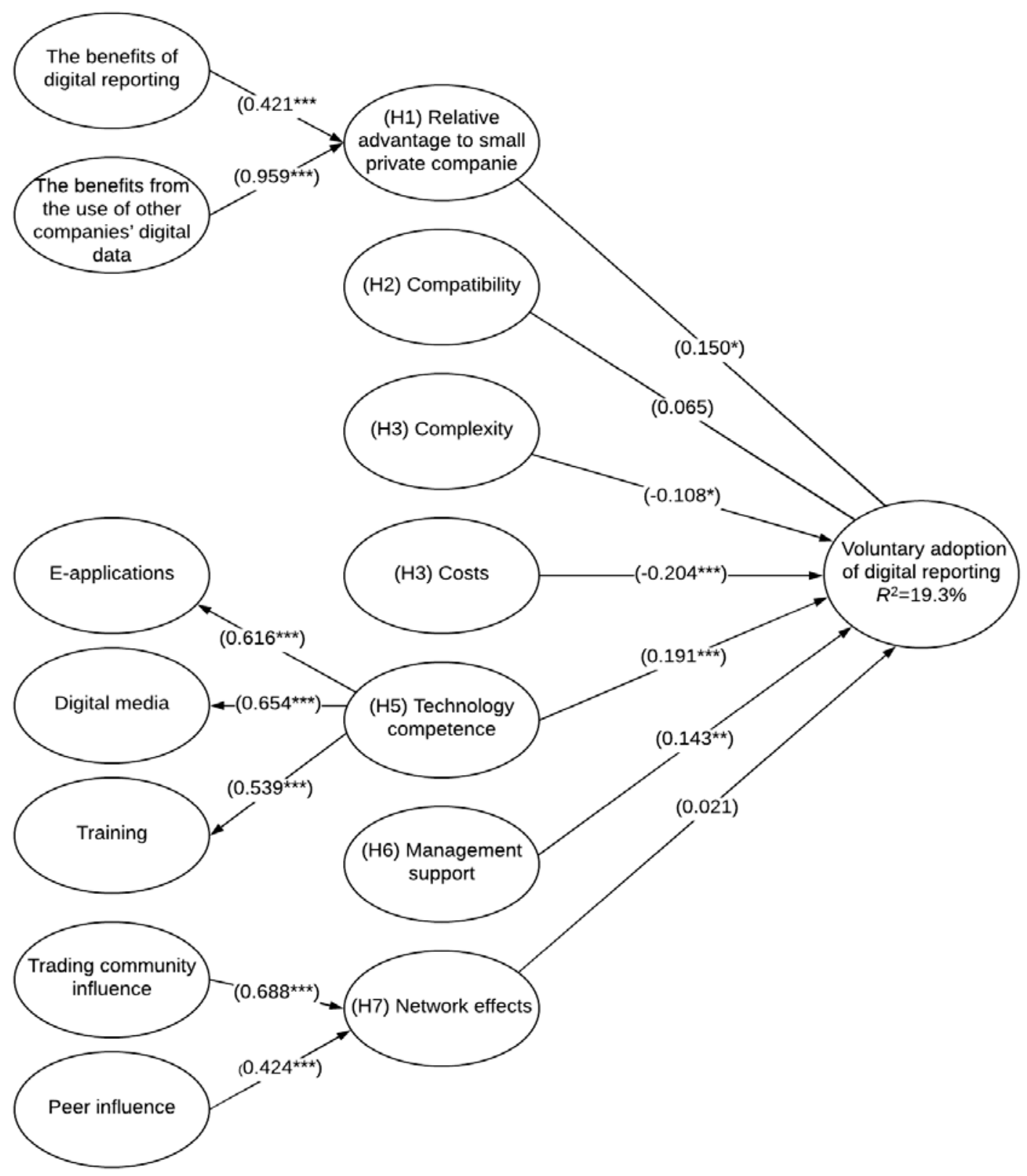

Note: ${ }^{* * *} p<0.001 ;{ }^{* *} p<0.01 ;{ }^{*} p<0.05$ 


\section{Discussion}

Our study investigates the research question: What are the factors that influence the voluntary adoption of digital reporting by small private companies? The results of our hypothesis testing provide answers based on the three contextual factors: the technology, organisation and business environment contexts (Tornatzky and Fleischer, 1990; Rogers, 1995). We identify five significant determinants of the voluntary adoption of digital reporting by small private companies at Companies House in the UK: three are within the technology context (relative advantage, complexity and costs) and two are within the organisation context (technology competence and management support). Table 8 summarizes the results of our hypothesis testing.

Table 8 Results of hypothesis testing

\begin{tabular}{|c|c|c|}
\hline Paths & Hypothesis & $\begin{array}{l}\text { Hypothesis } \\
\text { supported }\end{array}$ \\
\hline $\begin{array}{l}\text { Relative advantage } \rightarrow \text { Voluntary } \\
\text { adoption of digital reporting }\end{array}$ & $\begin{array}{l}\text { H1 The relative advantage of digitisation } \\
\text { positively influences the voluntary } \\
\text { adoption of digital reporting by small } \\
\text { private companies. }\end{array}$ & Yes \\
\hline $\begin{array}{l}\text { Compatibility } \rightarrow \text { The Voluntary } \\
\text { adoption of digital reporting }\end{array}$ & $\begin{array}{l}\text { H2 The compatibility of the company's } \\
\text { accounting system with the filing } \\
\text { software positively influences the } \\
\text { voluntary adoption of digital reporting } \\
\text { by small private companies. }\end{array}$ & No \\
\hline $\begin{array}{l}\text { Complexity } \rightarrow \text { Voluntary adoption of } \\
\text { digital reporting }\end{array}$ & $\begin{array}{l}\text { H3 The complexity of the filing process } \\
\text { inversely influences the voluntary } \\
\text { adoption of digital reporting by small } \\
\text { private companies. }\end{array}$ & Yes \\
\hline $\begin{array}{l}\text { Costs } \rightarrow \text { Voluntary adoption of digital } \\
\text { reporting }\end{array}$ & $\begin{array}{l}\text { H4 The company's technology costs } \\
\text { inversely influence the voluntary } \\
\text { adoption of digital reporting by small } \\
\text { private companies. }\end{array}$ & Yes \\
\hline $\begin{array}{l}\text { Technology competence } \rightarrow \text { Voluntary } \\
\text { adoption of digital reporting }\end{array}$ & $\begin{array}{l}\text { H5 The company's technological } \\
\text { competence positively influences the } \\
\text { voluntary adoption of digital reporting } \\
\text { by small private companies. }\end{array}$ & Yes \\
\hline $\begin{array}{l}\text { Management support } \rightarrow \text { Voluntary } \\
\text { adoption of digital reporting }\end{array}$ & $\begin{array}{l}\text { H6 Top management support positively } \\
\text { influences the voluntary adoption of } \\
\text { digital reporting by small private } \\
\text { companies. }\end{array}$ & Yes \\
\hline $\begin{array}{l}\text { Network effects } \rightarrow \text { Voluntary adoption } \\
\text { of digital reporting }\end{array}$ & $\begin{array}{l}\text { H7 Network effects positively influence the } \\
\text { voluntary adoption of digital reporting } \\
\text { by small private companies. }\end{array}$ & No \\
\hline
\end{tabular}




\section{Technology context}

Our results provide evidence that the relative advantage of digitisation positively influences the voluntary adoption of digital reporting by small private companies as indicated by the path coefficient in Figure $2(b=0.150, p<0.05)$. This result confirms our theoretical expectation and provides support for $\mathrm{H} 1$. We also examined the two sub-dimensions of the relative advantage as shown in Figure 2. As evident from the weights of both digital reporting benefits and benefits from the use of other companies' digital data to small private companies are significant $(p<0.001)$, supporting our conceptualization of the relative advantage as a secondorder formative structure.

Descriptive statistics (not tabulated) relating to the extent of agreement with five statements about the benefits of the digital reporting to small companies as they have been presented in our earlier study (Collis et al., 2018). At the top of the list is the convenience of the round-theclock facility (89\% agreed), followed by the speed of online filing (86\%). The majority (62\%) agree that digital filing is more accurate than paper filing. However, the results of this study suggest that just over half of those surveyed (53\%) consider that online filing ensure better compliance with statutory requirements than paper filing and (31\%) agree that there is any difference in the rejection rate with digital filing (Collis et al., 2018).

In addition, descriptive statistics on the extent of agreement with ten statements about the benefits of the use of other companies' digital data (not tabulated) are useful in revealing the underlying reasons, have been presented in our earlier study (Collis et al., 2018). First is faster access to information (89\% agree), agreement that the digital company search and data services provided by Companies House provide access to financial information on a continuous basis (86\% agree), followed by the low cost of acquiring the information (85\% agree), the data formats are easy to use (62\% agree), and the data is reliable information due to fewer filing errors (52\% agree). Some respondents considered there were other benefits: Definition of each component of the accounts is clear (46\% agree), and improved comparability (40\%) and improved analysis opportunities (39\% agree). Digital data enhances the efficiency of business decision-making (33\% agree) and it helps the user understand the different elements of the accounts (26\% agree). 
Prior research on technologies similar to XBRL has generally found relative advantage to be an important determinant of the technology adoption. For example, Wang et al. (2010) confirm that the idea of perceived benefits refers to the level of recognition of the relative advantage that an EDI technology can provide to the organization. Therefore, the concept of perceived benefits is part of the technical context in the diffusion of innovation theory and technology, organisation and environment framework. This is also consistent with the XBRL literature (Hodge et al., 2004; Baldwin et al., 2006; Bonson et al., 2009; Henderson et al., 2012; Eierle et al., 2014) where the relative advantage was found to be a significant factor driving the technology adoption. We add to prior literature by not only examining the standardisation benefits to the small private companies as filers themselves, but also the standardisation benefits arising from their use of the XBRL/iXBRL data filed by other small private companies that is available from the Companies House website. This study takes a coherent approach by examining two types of benefit that offer small private companies adopting digital reporting a relative advantage.

The path between compatibility and the voluntary adoption of digital reporting is positive but statistically insignificant $(p>0.05)$. Therefore, there is no evidence to support $\mathrm{H} 2$ that the compatibility of the company's accounting system with the filing software positively influences the voluntary adoption of digital reporting by small private companies. This result is contrary to previous studies undertaken in New Zealand (Cordery et al., 2011), Australia (Azam and Taylor, 2013; Lim and Perrin, 2014) and the USA (Henderson et al., 2012). The most likely explanation for this is that these prior studies were conducted before using XBRL was so widespread and, today, the reason is that the Internet makes data exchange between XBRL technology and other information systems easier. Thus, most Internet-based systems are compatible with modern information systems currently used by companies.

Another possible explanation is that most of these studies focus on large companies where use of XBRL technology requires substantial modification to their existing IT infrastructure. The compatibility, therefore, is a significant factor to make transferring data easier between different information systems and to make their processes compatible with new technology. In contrast, the UK's small companies can use digital reporting by downloading simple forms using WebFiling or Joint filing. Alternatively, they can use simple filing software to submit their accounts and returns either in XBRL or iXBRL formats at Companies House and/or HMRC. These digital reporting media do not require substantial modification in small companies' 
information systems. In this context, the compatibility with the company's accounting system is no longer a major concern. However, our evidence is consistent with research by Huang et al. (2008) and Picoto et al. (2014) who suggest that compatibility is not a significant problem since most Internet-based systems are already compatible with modern information systems. They argue that there is a need to further evaluate the diffusion of innovation theory in the context of organisational level studies where compatibility may be less relevant.

As predicted, complexity has an inverse influence on digital reporting, supporting H3 ( $b=$ $0.144, p<0.05)$. Our results show that digital reporting is complex for small companies as it requires extra effort to understand the new online filing process compared with traditional paper filing. We also find that separate digital reporting to HMRC and Companies House is cumbersome. Although a joint filing facility is available, at present the two agencies have different submission deadlines and awareness among small companies of the benefits of joint filing is limited. This confirms the findings of Dunne et al. (2009) who find that XBRL reporting is a complex process because of the time and effort needed to learn about XBRL among companies in the UK. Other studies confirm that the complexity of XBRL originates from the tagging process and systems integration issues which have a negative influence on the adoption decision (Pinsker and Li, 2008; Henderson et al., 2012).

The costs have a negative and significant path leading to the voluntary adoption of digital reporting ( $b=-0.204, p<0.001$ ). This provides evidence to support $\mathrm{H} 4$, suggesting that the company's technology costs inversely influence the voluntary adoption of digital reporting by small private companies. Our results show that most small companies use commercial filing software and consequently consider the software and set-up costs of digital reporting are high. Dunne et al. (2009) confirm that the cost of commercial filing software is a major burden on companies using XBRL in the UK. It also supports the evidence by Pinsker and Li (2008) who find the cost of XBRL technology is barrier to adoption by large listed companies. This differs from a study in Australia (Troshani and Rao, 2007) which reports that the cost of using XBRL technology is not high for early adopters.

\section{Organisation context}

The results show the company's technological competence positively influences the voluntary adoption of digital reporting by small private companies. ( $b=191, p<0.001)$, thus providing evidence to support H5. 
Prior research supports the importance of technology competence. For example, Hsu et al. (2006), Zhu et al. (2006b) and Picoto et al. (2014) find that technology competence is the most significant determinant of the use or adoption of e-business among the factors studied. Our results demonstrate that the three dimensions (E-APPLICATIONS, DIGITALMEDIA and TRAINING) are the factors underlying technology competence, are significant $(p<0.001)$. Thus, small private companies with a higher level of technology competence tend to enjoy greater readiness for the voluntary adoption of digital reporting to Companies House. However, we conclude that digital reporting does not require technical training or expertise in XBRL as the technology that underpins the filing software is not visible to the filer.

Management support has a positive and significant path leading to the voluntary adoption of digital reporting by small private companies $(b=0.143, p<0.01)$. This provides evidence to support H6 that management support positively influences the voluntary adoption of digital reporting by small private companies. Our results show that in small companies enthusiastic support for digital reporting is needed from the principal director and the company needs to allocate adequate financial resources to support the move from paper filing. This is consistent with previous studies (Lia et al., 2007; Huang et al., 2008) where support from top management is a critical factor in the context of technological innovation, particularly in small businesses. This ensures there are adequate resources and an organisational champion to implement the innovation and overcome any resistance to change (Premkumar et al., 1997).

\section{Business environment context}

The path from network effects to the voluntary adoption of digital reporting is not significant $(p>0.05)$. Therefore, there is no evidence to support $\mathrm{H} 7$ that network effects positively influence the voluntary adoption of digital reporting by small private companies. To gain a finer-grained understanding of factors influencing digital reporting network effects, its underlying dimensions were also tested. The result suggests that trading community influence $(p<0.001)$ and peer influence $(p<0.001)$ are both significant, which are consistent with our theoretical predictions and support our second-order conceptualization. More specifically, the digital reporting decision in small companies is not influenced by the trading community (customers and suppliers) or competitors. This is contrary to the results of Zhu et al. (2006b) and Lai et al. (2007), but supports those of Huang et al. (2008) who report that network effects are not significantly related to EDI adoption. Doolin and Troshani (2007) suggest that technology adoption in Australia depends on a critical mass of customers, suppliers and 
competitors. However, our study shows that this is not the case in the context of digital reporting by small private companies in the UK.

\section{Conclusions}

Some 2.3 million companies in the UK have a statutory obligation to file digital financial information in XBRL/iXBRL to HMRC for tax purposes and almost 2.2 million small private companies voluntarily use digital reporting to fulfil their corporate reporting obligations to Companies House (FRC, 2017). Many use the joint filing facility that offers a single template or 'one-stop shop' for simultaneously fulfilling their statutory filing obligations to HMRC and Companies House.

To the authors' knowledge, this is the first study to investigate the costs and benefits of the voluntary adoption of digital reporting to Companies House by small private companies after its introduction in 2011. The study makes several contributions to the literature. It enhances our knowledge of how the digitisation of financial information affects small private companies and identifies the determinants of the voluntary adoption of digital reporting by such companies. It also provides a holistic view of the standardisation benefits to small private companies. Moreover, it extends the literature by identifying the actual benefits to filers and users, whereas previous studies focus on the expected benefits of XBRL (e.g., Vasarhelyi et al., 2010).

This study contributes to theory in two ways. The first and major contribution is that is enhances the conceptualisation and operationalisation of relative advantage as a formative and secondorder construct by examining two types of the benefits to small private companies: benefits from the adoption of digital reporting to Companies House and benefits from their use of the XBRL/iXBRL data of other companies provided by Companies House. This provides further understanding of the standardisation benefits of using XBRL/iXBRL filing formats. Second, we replace the general technologies used to measure technology competence in previous studies (e.g., Zhu et al., 2006b) with specific technologies for digital reporting in the UK, such as WebFiling and joint filing.

Our results have a number of implications for practice. Accountants working in small companies and accountants in practice with small company clients are the main filers of the digital accounts and returns. Therefore, they are in a strong position to advise small private companies on the process of digital reporting and increase awareness of the joint filing facility. The principal directors of small private companies should weigh up the costs and benefits of 
digital reporting. They should be informed that technical knowledge and skills are not needed. Support from top management is important for overcoming any obstacles to digital reporting. HMRC and Companies House should take steps to increase awareness of the benefits of joint filing by publishing a business case for the joint filing facility. The benefits of using other companies’ digital data provided by Companies House should also receive increased publicity. Finally, policy makers seeking to reduce regulatory burdens on smaller entities should consider extending the scope to medium-sized companies.

This study has four limitations which offer avenues for future research. First, caution should be taken when comparing our results with other studies because the criteria for defining small private companies vary over time and across countries. Nevertheless, there is an opportunity to conduct further research in other countries to validate the theoretical model. Second, we are not able to determine the response rate to our survey as the population of ACCA members working in small private companies or with small company clients in the UK is not known. If it is an estimated 20,000, our sample size of 343 is slightly lower than the theoretical minimum of 377 proposed by Krejcie and Morgan (1970, p. 608). While we believe that our sample still has a high chance of representing the population, this leaves scope for a larger study.

Third, this study examines the influence of network effects in the business environment on the voluntary adoption of digital reporting. However, future research might also examine the role of government policy and the technology support infrastructure, such as the availability of filing software provided by government and commercial vendors, that might also contribute to the voluntary adoption decision, as suggested by previous studies (e.g. Henderson et al., 2012; Picoto et al., 2014) where those factors positively influence the adoption of new technology. Fourth, other technology characteristics of innovation, such as observability and trialability, may also influence the adoption of digital reporting. Therefore, future research could incorporate these variables in the model to enhance our understanding of the causality relationship between the variables.

Despite the above limitations, the results of this study should be of interest to the directors of small private companies and their accountants. They will also be of interest to regulators in the other jurisdictions planning similar digital reporting initiatives or seeking to reduce the administrative burdens on smaller entities. 


\section{Acknowledgements}

We would like to thank the Association of Chartered Certified Accountants for disseminating the questionnaire to their UK members. We are also grateful to the participants of $13^{\text {th }}$ Annual Workshop on Financial Reporting in Europe, 2017, Florence, Italy and Symposium of Auditing and Assessment, 2017, Tampere, Finland for their valuable feedback.

\section{References}

Alles, M. and Piechocki, M., 2012. Will XBRL improve corporate governance?: A framework for enhancing governance decision making using interactive data. International Journal of Accounting Information Systems, 13(2), pp. 91-108.

Baldwin, A.A. and Trinkle, B.S., 2011. The impact of XBRL: A Delphi investigation. The International Journal of Digital Accounting Research, 11(17), pp. 1-24.

Baldwin, A.A., Brown, C.E. and Trinkle, B.S., 2006. XBRL: An impacts framework and research challenge. Journal of Emerging Technologies in Accounting, 3(1), pp. 97-116.

Bartley, J., Chen, A.Y.S. and Taylor, E., 2010. Avoiding common errors of XBRL implementation. Journal of Accountancy, 209(2), pp. 46-51.

BEIS, 2018. Business Population Estimates for the UK and regions. Department for Business, Energy \& Industrial Strategy. https://www.gov.uk/government/statistics/business-populationestimates-2018 (Accessed: 26 February 2019).

BIS, 2009. Better regulation simplification plan 2009: Delivering a better business environment. Department for Business Innovation \& http://webarchive.nationalarchives.gov.uk/20090609003228/http://www.berr.gov.uk/files/file5 3978.pdf (Accessed: 3 June 2018).

Bollen, K.A., 1998. Structural equation models, in Armitage P, Colton T (Eds.) Encyclopaedia of Biostatistics. New York: Wiley, pp. 4363-4372.

Bonsón, E., Cortijo, V. and Escobar, T., 2009. Towards the global adoption of XBRL using International Financial Reporting Standards (IFRS). International Journal of Accounting Information Systems, 10(1), pp. 46-60.

Chau, P. Y. and Tam, K. Y., 1997. Factors affecting the adoption of open systems: an exploratory study. MIS Quarterly, 21(1), pp. 1-24.

Chin, W.W., and Gopal, A., 1995. Adoption Intention in GSS: Relative Importance of Beliefs. Data Base, 26 (2), pp. 42-63.

Chin, W.W., 1998. The partial least squares approach to structural equation modeling. Modern methods for business research, 295(2), pp. 295-336.

Chwelos, P., Benbasat, I. and Dexter, A., 2001. Research report: empirical test of an EDI adoption model. Information System Research, 12(3), pp. 304-321. 
Cohen, E.E., Debreceny, R., Farewell, S. and Roohani, S., 2014. Issues with the communication and integrity of audit reports when financial reporting shifts to an information-centric paradigm. International Journal of Accounting Information Systems, 15(4), pp. 400-422.

Collis, J., 2012. Determinants of voluntary audit and voluntary full accounts in micro-and non-micro small companies in the UK. Accounting and Business Research, 42(4), pp. 441-468.

Collis, J., Alkhatib, E. and de Cesare, S., 2018. Costs and benefits to small companies of digital reporting. http://www.accaglobal.com/content/dam/ACCA_Global/Technical/tax/Alkhatib\%20et\%20al \%20Small\%20Company\%20Digital\%20Reporting\%20Jan\%202018.pdf

(Accessed:15 February 2019).

Companies House, 2013a. Inline XBRL (iXBRL) FAQs. http://webarchive.nationalarchives.gov.uk/20140711183307/http://www.companieshouse.gov. uk/about/miscellaneous/jointFilingSoftwareFilingFAQs.shtml (Accessed: 4 June 2018).

Companies House, 2013b. XBRL company accounts. https://ewf.companieshouse.gov.uk/xbrl (Accessed: 4 June 2018).

Companies House, 2015. Companies House business plan 2015-2016. https://www.gov.uk/government/publications/companies-house-business-plan-2015-to-2016 (Accessed: 17 February 2019).

Deshmukh, A., 2004. XBRL. The Communications of the Association for Information Systems, 13(1), p. 55.

Dhole, S., Lobo, G.J., Mishra, S. and Pal, A.M., 2015. Effects of the SEC's XBRL mandate on financial reporting comparability. International Journal of Accounting Information Systems, 19, pp. 2944.

Diamantopoulos, A., Riefler, P. and Roth, K.P., 2008. Advancing formative measurement models. Journal of business research, 61(12), pp.1203-1218.

Doolin, B. and Troshani, I., 2007. Organizational adoption of XBRL. Electronic Markets, 17(3), pp. 199-209.

Dunne, T., Helliar, C., Lymer, A. and Mousa, R., 2009. XBRL: The Views of the Stakeholders: Executive Summary. Association of Chartered Certified Accountants. http://www.accaglobal.com/content/dam/acca/global/PDF-technical/technologypublications/rr-111-002.pdf (Accessed: 16 February 2019).

Dunne, T., Helliar, C., Lymer, A. and Mousa, R., 2013. Stakeholder engagement in internet financial reporting: The diffusion of XBRL in the UK. The British Accounting Review, 45(3), pp.167182.

Eierle, B., Ojala, H. and Penttinen, E., 2014. XBRL to enhance external financial reporting: Should we implement or not? Case Company X. Journal of Accounting Education, 32(2), pp. 160-170.

Farewell, S. and Pinsker, R., 2005. XBRL and financial information assurance services. The CPA Journal, 75(5), p. 68. 
Fornell, C. and Larcker, D.F., 1981. Structural equation models with unobservable variables and measurement error: Algebra and statistics. Journal of Marketing Research, 18, pp. 382-388.

FRC, 2017. XBRL: Deep-dive: Digital future of corporate reporting. London: Financial Reporting Council. $\quad$ https://www.frc.org.uk/getattachment/9279091c-a4e9-4389-bdd6d8dc5563b14a/DigFutureXBRLDec.pdf (Accessed: 12 May 2018).

Gefen, D. and Straub, D., 2005. A practical guide to factorial validity using PLS-Graph: Tutorial and annotated example. Communications of the Association for Information systems, 16(1), p. 5.

Gefen, D., Straub, D.W. and Rigdon, E.E., 2011. An update and extension to SEM guidelines for admnistrative and social science research. MIS Quarterly, 35(2), pp. iii-A7.

Gerbing, D.W. and Anderson, J.C., 1988. An updated paradigm for scale development incorporating unidimensionality and its assessment. Journal of marketing research, 25(2), pp. 186-192.

Goodhue, D.L., Wybo, M.D. and Kirsch, L.J., 1992. The impact of data integration on the costs and benefits of information systems. MIS Quarterly, pp. 293-311

Guilloux, V., Locke, J. and Lowe, A., 2013. Digital business reporting standards: mapping the battle in France. European Journal of Information Systems, 22(3), pp. 257-277.

Grandon, E.E. and Pearson, J.M., 2004. Electronic commerce adoption: an empirical study of small and medium US businesses. Information \& Management, 42(1), pp. 197-216.

Hair Jr, J.F., Hult, G.T.M., Ringle, C. and Sarstedt, M., 2016. A primer on partial least squares structural equation modeling (PLS-SEM). Sage Publications.

Hair, J.F., Ringle, C.M. and Sarstedt, M., 2011. PLS-SEM: Indeed a silver bullet. Journal of Marketing theory and Practice, 19(2), pp. 139-152.

Hair, J.F., Sarstedt, J. M., Hopkins, L. and Kuppelwieser, G.V., 2014. Partial least squares structural equation modeling (PLS-SEM) An emerging tool in business research. European Business Review, 26(2), pp. 106-121.

Henderson, D., Sheetz, S.D. and Trinkle, B.S., 2012. The determinants of inter-organizational and internal in-house adoption of XBRL: A structural equation model. International Journal of Accounting Information Systems, 13(2), pp. 109-140.

Henseler, J., Dijkstra, T.K., Sarstedt, M., Ringle, C.M., Diamantopoulos, A., Straub, D.W., Ketchen Jr, D.J., Hair, J.F., Hult, G.T.M. and Calantone, R.J., 2014. Common beliefs and reality about PLS: Comments on Rönkkö and Evermann (2013). Organizational Research Methods, 17(2), pp. 182-209.

Henseler, J., Ringle, C.M. and Sinkovics, R.R., 2009. The use of partial least squares path modeling in international marketing. In New Challenges to International Marketing, 20(1), pp. 277-319.

Hinkin, T.R., 1998. A brief tutorial on the development of measures for use in survey questionnaires. Organizational research methods, 1(1), pp. 104-121.

HMRC, 2011. XBRL guide for UK businesses. HM Revenue \& Customs. http://www.hmrc.gov.uk/ct/ct-online/file-return/xbrl-guide.pdf (Accessed: 3 June 2018). 
HMRC, 2017. Making tax digital (updated 8 March 2017). HM Revenue \& Customs. https://www.gov.uk/government/publications/making-tax-digital (Accessed: 12 May 2018).

Hodge, F.D., Kennedy, J.J. and Maines, L.A., 2004. Does search-facilitating technology improve the transparency of financial reporting?. The Accounting Review, 79(3), pp. 687-703.

Hoelter, J.W., 1983. The analysis of covariance structures: Goodness-of-fit indices. Sociological Methods \& Research, 11(3), pp. 325-344.

Hsu, P.F., Kraemer, K.L. and Dunkle, D., 2006. Determinants of e-business use in US firms. International Journal of Electronic Commerce, 10(4), pp. 9-45.

Huang, Z., Janz, B.D. and Frolick, M.N., 2008. A comprehensive examination of Internet-EDI adoption. Information Systems Management, 25(3), pp. 273-28.

Iacovou, C. L., Benbasat, I. and Dexter, A. S., 1995. Electronic data interchange and small organisations: Adoption and impact of technology. MIS Quarterly, pp. 465-485.

ICAEW, 2004. Digital reporting: A progress report (information for better markets). London: Institute of Chartered Accountants in England \& Wales. http://www.icaew.com/ /media/corporate/files/technical/financial\%20reporting/information\% 20for\%20better\%20markets/ifbm/digital\%20reporting\%20a\%20progress\%20report.ashx (Accessed: 3 June 2018).

Katz, M.L. and Shapiro, C., 1994. Systems competition and network effects. Journal of economic perspectives, 8(2), pp. 93-115.

Kindleberger, C.P., 1983. Standards as public, collective and private goods. Kyklos, 36(3), pp.377-396.

KPMG, 2006. Administrative Burdens: HMRC Measurement Project, London: KPMG. http://www.hmrc.gov.uk/better-regulation/kpmg1.pdf(Accessed 3 June 2018).

Krejcie, R.V. and Morgan, D.W., 1970. Determining sample size for research activities. Educational and psychological measurement, 30(3), pp. 607-610.

Kuan, K.K. and Chau, P.Y., 2001. A perception-based model for EDI adoption in small businesses using a technology-organization-environment framework. Information \& Management, 38(8), pp. 507-521.

Lai, F., Wang, J., Hsieh, C.T. and Chen, J.C., 2007. On network externalities, e-business adoption and information asymmetry. Industrial Management \& Data Systems, 107(5), pp. 728-746.

Lim, N. and Perrin, B., 2014. Standard business reporting in Australia: Past, present, and future. Australasian Journal of Information Systems, 18(3).

Lin, C.P. and Bhattacherjee, A., 2008. Elucidating individual intention to use interactive information technologies: The role of network externalities. International Journal of Electronic Commerce, 13(1), pp. 85-108.

Lymer, A., Debreceny, R., Gray, G.L. and Rahman, A., 1999. Business reporting on the Internet. London: International Accounting Standards Committee. https://www.icjce.es/images/pdfs/TECNICA/C02\%20-\%20IASB/C208\%20-\%20IASB\%20\%20Estudios\%20y\%20varios/BusinessReportingInternet-IASC.pdf (Accessed: 4 June 2018). 
Lymer, A., Hansford, A. and Pilkington, K., 2012. Developments in tax e-filing: practical views from the coalface. Journal of Applied Accounting Research, 13(3), pp. 212-225.

Markus, M.L., Steinfield, C.W. and Wigand, R.T., 2006. Industry-wide information systems standardization as collective action: the case of the US residential mortgage industry. MIS Quarterly, 30(Special Issue), pp. 439-465.

Moore, G.C. and Benbasat, I., 1991. Development of an instrument to measure the perceptions of adopting an information technology innovation. Information Systems Research, 2(3), pp. 192222.

Mousa, R., 2013. E-Government adoption in the UK: XBRL project. International Journal of Electronic Government Research, 9(2), pp. 101-119.

Ojala, H., Penttinen, E., Collis, J. and Virtanen, T., 2018. Design principles for Standard Business Reporting (SBR) taxonomy development: Evidence from Finland. Nordic Journal of Business, 67(1), pp. 4-26.

O'Riain, S., Curry, E. and Harth, A., 2012. XBRL and open data for global financial ecosystems: A linked data approach. International Journal of Accounting Information Systems, 13(2), pp. 141162.

Pan, M.J. and Jang, W.Y., 2008. Determinants of the adoption of enterprise resource planning within the technology-organization-environment framework: Taiwan's communications industry. Journal of Computer Information Systems, 48(3), pp. 94-102.

Petter, S., Straub, D.W. and Rai, A., 2007. Specifying formative constructs in information systems research. MIS Quarterly, 31(4), pp. 623-656.

Picoto, W.N., Bélanger, F. and Palma-dos-Reis, A., 2014. An organizational perspective on m-business: usage factors and value determination. European Journal of Information Systems, 23(5), pp. 571-592.

Piechocki, M., Felden, C., Gräning, A. and Debreceny, R., 2009. Design and standardisation of XBRL solutions for governance and transparency. International Journal of Disclosure and Governance, 6(3), pp. 224-240.

Pinsker, R., 2003. XBRL awareness in auditing: a sleeping giant?. Managerial Auditing Journal, 18(9), pp. 732-736.

Pinsker, R. and Li, S., 2008. Costs and benefits of XBRL adoption: Early evidence. Communications of the ACM, 51(3), p. 47.

Podsakoff, P.M., MacKenzie, S.B., Lee, J.Y. and Podsakoff, N.P., 2003. Common method biases in behavioral research: A critical review of the literature and recommended remedies. Journal of Applied Psychology, 88(5), p. 879.

Premuroso, R.F. and Bhattacharya, S., 2008. Do early and voluntary filers of financial information in XBRL format signal superior corporate governance and operating performance?. International Journal of Accounting Information Systems, 9(1), pp. 1-20.

Premkumar, G., Ramamurthy, K. and Crum, M., 1997. Determinants of EDI adoption in the transportation industry. European Journal of Information Systems, 6(2), pp. 107-121. 
PricewaterhouseCoopers (PwC) 2004. Technology forecast: XBRL improving business reporting through standardisation. http://www.xbrl.org/Business/Companies/PwC_XBRL_Standardization.pdf (Accessed: 26 April 2018).

Robb, D.A., Rohde, F.H. and Green, P.F., 2016. Standard Business Reporting in Australia: efficiency, effectiveness, or both?. Accounting \& Finance, 56(2), pp. 509-544.

Rogers, E.M., 1983. Diffusion of innovations, 3th edn. New York, Free Press.

Rogers, E.M., 1995. Diffusion of innovations, 4th edn. New York, Free Press.

Rogers, E.M., 2003. Diffusion of Innovations, 5th edn. New York, Free Press.

Roohani, S.J. and Zheng, X., 2011. Determinants of the deficiency of XBRL mandatory filings. Applied Finance, p. 502.

Sinnett, W.M. and Willis, M., 2009. The time is right for Standard Business Reporting: the concept of common compliance requirements for all regulatory reporting and legislation is gaining steam. Who's on board? What steps are being taken? What's expected?. Financial Executive, 25(9), pp. 23-28.

Stewart, K.A. and Segars, A.H., 2002. An empirical examination of the concern for information privacy instrument. Information Systems Research, 13(1), pp. 36-49

Straub, D.W., 1989. Validating instruments in MIS research. MIS Quarterly, June, pp. 147-169.

Teo, H. H., Wei, K. K. and Benbasat, I., 2003. Predicting intention to adopt Interorganisational linkages: An institutional perspective. MIS Quarterly, 27(1), pp. 19-49.

Tornatzky, L. and Fleischer, M. 1990. The process of technology innovation. Lexington, MA: Lexington Books.

Thong, J. Y., 1999. An integrated model of information systems adoption in small businesses. Journal of Management Information Systems, 15(4), pp. 187-214.

Tornatzky, L. and Fleischer, M. 1990. The process of technology innovation. Lexington, MA: Lexington Books.

Tornatzky, L.G. and Klein, K.J. 1982. Innovation characteristics and innovation adoptionimplementation: A meta-analysis of findings. IEEE Transactions on Engineering Management, 29(1), pp.28-45.

Troshani, I. and Rao, S., 2007. Drivers and inhibitors to XBRL adoption: A qualitative approach to build a theory in under-researched areas. International Journal of E-Business Research (IJEBR), 3(4), pp. 98-111.

Troshani, I., Parker, L.D. and Lymer, A., 2015. Institutionalising XBRL for financial reporting: resorting to regulation. Accounting and Business Research, 45(2), pp. 196-228.

Troshani, I. and Lymer, A., 2010. Translation in XBRL standardization. Information Technology \& People, 23(2), pp.136-164. 
Valentinetti, D. and Rea, M.A., 2012. IFRS Taxonomy and financial reporting practices: The case of Italian listed companies. International Journal of Accounting Information Systems, 13(2), pp. 163-180.

Vasarhelyi, M.A., Chan, D.Y. and Krahel, J.P., 2010. XBRL consequences to financial reporting, data analysis, decision support, and others. Rutgers University, New Jersey, USA. http://eycarat.faculty.ku.edu/myssi/_pdf/4-Miklos-Chan-Alles-XBRL-Consequences.pdf (Accessed: 16 February 2019).

Vasarhelyi, M.A., Chan, D.Y. and Krahel, J.P., 2012. Consequences of XBRL standardization on financial statement data. Journal of Information Systems, 26(1), pp. 155-167.

Wang, Y.M., Wang, Y.S. and Yang, Y.F., 2010. Understanding the determinants of RFID adoption in the manufacturing industry. Technological Forecasting and Social Change, 77(5), pp. 803-815.

Weitzel, T., Beimborn, D. and König, W., 2006. A unified economic model of standard diffusion: the impact of standardization cost, network effects, and network topology. MIS Quarterly, 30(1) pp. 489-514.

Wright, R.T., Campbell, D.E., Thatcher, J.B. and Roberts, N.H., 2012. Operationalizing Multidimensional Constructs in Structural Equation Modeling: Recommendations for IS Research. CAIS, 30(23), pp. 367-412.

Zhu, K. and Kraemer, K.L., 2005. Post-adoption variations in usage and value of e-business by organizations: cross-country evidence from the retail industry. Information Systems Research, 16(1), pp. 61-84.

Zhu, K., Dong, S., Xu, S.X. and Kraemer, K.L., 2006a. Innovation diffusion in global contexts: determinants of post-adoption digital transformation of European companies. European Journal of Information Systems, 15(6), pp. 601-616.

Zhu, K., Kraemer, K.L. and Xu, S., 2006b. The process of innovation assimilation by firms in different countries: a technology diffusion perspective on e-business. Management Science, 52(10), pp $.1557-1576$

Zhu, K., Kraemer, K.L., Gurbaxani, V. and Xu, S.X., 2006c. Migration to open-standard interorganizational systems: network effects, switching costs, and path dependency. MIS Quarterly, 30(Special Issue), pp. 515-538 


\section{Appendix A}

Measurement indicators: First-order constructs

\begin{tabular}{|c|c|c|c|}
\hline Construct (Type) & Code & Indicator & Source \\
\hline \multirow[t]{3}{*}{$\begin{array}{l}\text { Compatibility } \\
\text { (Reflective) }\end{array}$} & DATATRANSFER ${ }^{a}$ & $\begin{array}{l}\text { Digital filing makes transferring data easier between different information systems than } \\
\text { paper filing }\end{array}$ & $\begin{array}{l}\text { Adapted from Dunne et } \\
\text { al. (2009), Wang et al. }\end{array}$ \\
\hline & ITMODIFYING & Digital filing requires substantial modification in existing IT infrastructure & (2010), Henderson et al. \\
\hline & ACSTANDARDS & $\begin{array}{l}\text { Paper filing is more consistent with existing accounting standards compared with digital } \\
\text { filing }\end{array}$ & $\begin{array}{l}\text { (2012) and Picoto et al. } \\
\text { (2014) }\end{array}$ \\
\hline \multirow[t]{2}{*}{$\begin{array}{l}\text { Complexity } \\
\text { (Reflective) }\end{array}$} & $\begin{array}{l}\text { EFFORT } \\
\text { SIMPLICITY }\end{array}$ & $\begin{array}{l}\text { Paper filing requires extra effort to use compared to digital filing } \\
\text { Digital filing is less complex to understand than paper filing }\end{array}$ & $\begin{array}{l}\text { Wang et al. (2010), } \\
\text { Henderson et al. (2012) } \\
\text { and Picoto et al. (2014) }\end{array}$ \\
\hline & $B U R D E N$ & $\begin{array}{l}\text { Having to submit separate digital filings with Companies House and HMRC (instead of } \\
\text { one) is cumbersome }\end{array}$ & Interview findings \\
\hline \multirow{3}{*}{$\begin{array}{l}\text { Costs } \\
\text { (Reflective) }\end{array}$} & TRAINCOST $^{a}$ & Training cost to use digital filing is high & \multirow{3}{*}{$\begin{array}{l}\text { Kuan and Chau (2001), } \\
\text { Zhu et al. (2006c) and } \\
\text { Dunne et al. (2009) }\end{array}$} \\
\hline & SETUPCOST & Set-up/running cost of using digital filing is free & \\
\hline & SOFTWARECOST & Cost of the commercial software to produce online documents is high & \\
\hline \multirow{2}{*}{$\begin{array}{l}\text { Management } \\
\text { support } \\
\text { (Reflective) }\end{array}$} & FUNDING & $\begin{array}{l}\text { The organisation has allocated adequate financial resources to support the use of } \\
\text { digital filing }\end{array}$ & \multirow{2}{*}{$\begin{array}{l}\text { Wang et al. (2010) and } \\
\text { Huang et al. (2008) }\end{array}$} \\
\hline & CHAMPIONING & $\begin{array}{l}\text { The principal director enthusiastically supports the use of digital filing for the accounts } \\
\text { and returns rather than paper }\end{array}$ & \\
\hline $\begin{array}{l}\text { Voluntary adoption } \\
\text { of digital reporting } \\
\text { (Reflective) }\end{array}$ & $\begin{array}{l}\text { STATACS } \\
\text { ANNURET }\end{array}$ & The accountant files online statutory accounts at Companies House & $\begin{array}{l}\text { Bergeron (2003), Choi et } \\
\text { al. (2008) and } \\
\text { Henderson et al. (2012) }\end{array}$ \\
\hline
\end{tabular}

${ }^{a}$ Item marked for deletion 


\section{Appendix B}

\section{Measurement indicators: Second-order constructs}

\begin{tabular}{|c|c|c|c|}
\hline $\begin{array}{l}\text { Second-order } \\
\text { construct (Type) }\end{array}$ & Subconstructs (Type) & Indicator & Source \\
\hline \multirow[t]{5}{*}{$\begin{array}{l}\text { Technology } \\
\text { competence } \\
\text { (Reflective) }\end{array}$} & $\begin{array}{l}\text { E-applications } \\
\text { (Reflective) }\end{array}$ & $\begin{array}{l}\text { The company uses e-applications: } \\
\text { e-invoicing with customers } \\
\text { e-invoicing from suppliers } \\
\text { e-banking, Companies House eBilling } \\
\text { Companies House mobile applications } \\
\text { Familiarity with e- applications has encouraged the company decision to use } \\
\text { digital filing }\end{array}$ & \multirow[t]{5}{*}{$\begin{array}{l}\text { Teo et al. (2003), Zhu } \\
\text { and Kraemer (2005), } \\
\text { Doolin and Troshani } \\
\text { (2007), Wang et al. } \\
\text { (2010), Henderson et al. } \\
(2012) \text { and Picoto et al. } \\
(2014)\end{array}$} \\
\hline & $\begin{array}{l}\text { Digital media } \\
\text { (Reflective) }\end{array}$ & $\begin{array}{l}\text { The company uses digital media to submit the statutory accounts and/or returns } \\
\text { online: } \\
\text { The free HMRC digital filing software } \\
\text { Web Filing at Companies House } \\
\text { Commercial filing software } \\
\text { Joint filing with HMRC and Companies House simultaneously }\end{array}$ & \\
\hline & $\begin{array}{l}\text { Training } \\
\text { (Reflective) }\end{array}$ & $\begin{array}{l}\text { The accountant receives training in digital filing: in-house training (at company) } \\
\text { Software vendor training } \\
\text { Training at HMRC } \\
\text { Training at Companies House } \\
\text { Self-training using online tutorials }\end{array}$ & \\
\hline & $\begin{array}{l}\text { Technical expertise }{ }^{\mathbf{a}} \\
\text { (Single item) }\end{array}$ & Digital filing requires special technical expertise in-house & \\
\hline & $\begin{array}{l}\text { Special training } \\
\text { (Single item) }\end{array}$ & Digital filing requires more specialist training for accountants & \\
\hline \multirow[t]{3}{*}{$\begin{array}{l}\text { Network effects } \\
\text { (Formative) }\end{array}$} & \multirow{2}{*}{$\begin{array}{l}\text { Trading community } \\
\text { partners } \\
\text { (Formative) }\end{array}$} & $\begin{array}{l}\text { CUSTOMERS: The company's decision to use digital filing is influenced by } \\
\text { requests from customers/clients }\end{array}$ & \multirow{3}{*}{$\begin{array}{l}\text { Zhu et al. (2006c), Wang } \\
\text { et al. (2010), Doolin and } \\
\text { Troshani (2007), Huang } \\
\text { et al. (2008) }\end{array}$} \\
\hline & & $\begin{array}{l}\text { SUPPLIERS: The company’s decision to use digital filing is influenced by } \\
\text { suppliers }\end{array}$ & \\
\hline & $\begin{array}{l}\text { Peer influence } \\
\text { (Single item) }\end{array}$ & $\begin{array}{l}\text { COMPETITORS: The company's decision to use digital filing is influenced by a } \\
\text { recommendation from a colleague in another company in same industry }\end{array}$ & \\
\hline
\end{tabular}




\begin{tabular}{|c|c|c|c|}
\hline $\begin{array}{l}\text { Second-order } \\
\text { construct (Type) }\end{array}$ & Subconstructs (Type) & Indicator & Source \\
\hline \multirow{16}{*}{$\begin{array}{l}\text { Relative advantage } \\
\text { (Formative) }\end{array}$} & \multirow{6}{*}{$\begin{array}{l}\text { Digital reporting benefits } \\
\text { to small private companies } \\
\text { (Formative) }\end{array}$} & SPEED: Digital filing is faster than paper filing & \multirow{4}{*}{$\begin{array}{l}\text { Iacovou et al. (1995), } \\
\text { Hodge et al. (2004), } \\
\text { Doolin and Troshani } \\
\text { (2007), Bonson et al. } \\
\text { (2009) and Baldwin and } \\
\text { Trinkle (2011) }\end{array}$} \\
\hline & & CONVENIENT: Digital filing is more convenient because it is available 24/7 & \\
\hline & & ACCURACY: Digital filing is more accurate because there are fewer filing errors & \\
\hline & & $\begin{array}{l}\text { REJECTION: More documents are rejected with paper filing than with digital } \\
\text { filing }\end{array}$ & \\
\hline & & $\begin{array}{l}\text { COMPLIANCE: Digital filing ensures better compliance with statutory } \\
\text { requirements than paper filing }\end{array}$ & Interview findings \\
\hline & & CREDITDECISION $^{a}$ : Paper filing speeds up decisions by credit rating agencies & Interview findings \\
\hline & \multirow{10}{*}{$\begin{array}{l}\text { Benefits to small private } \\
\text { companies from the use of } \\
\text { other companies' digital } \\
\text { data (Formative) }\end{array}$} & $\begin{array}{l}\text { FASTERACCESS: Use of Companies House digital services speeds up the } \\
\text { accessibility of information }\end{array}$ & \multirow{10}{*}{$\begin{array}{l}\text { Hodge et al. (2004), } \\
\text { Baldwin et al. (2006), } \\
\text { Bonson et al. (2009) and } \\
\text { Henderson et al. (2012) }\end{array}$} \\
\hline & & $\begin{array}{l}\text { LOWCOST: The cost of acquiring information from Companies House digital } \\
\text { services is low }\end{array}$ & \\
\hline & & $\begin{array}{l}\text { CLEAR: Use of Companies House digital services provides a clear definition of } \\
\text { each component of the accounts }\end{array}$ & \\
\hline & & $\begin{array}{l}\text { USABILITY: Digital corporate data is provided by Companies House in formats } \\
\text { that are easy to use }\end{array}$ & \\
\hline & & $\begin{array}{l}\text { RELIABLE: Use of Companies House digital services provides reliable } \\
\text { information as there are fewer filing errors }\end{array}$ & \\
\hline & & $\begin{array}{l}\text { UNDERSTANDABLE: Use of Companies House digital services helps users to } \\
\text { understand the different elements of the accounts }\end{array}$ & \\
\hline & & $\begin{array}{l}\text { COMPARABLE: Use of Companies House digital services enhances the ability } \\
\text { to compare data }\end{array}$ & \\
\hline & & $\begin{array}{l}\text { MANIPULATABLE: Use of Companies House digital services improves analysis } \\
\text { opportunities }\end{array}$ & \\
\hline & & $\begin{array}{l}\text { EFFIECDECISION: Use of Companies House digital services enhances the } \\
\text { efficiency of business decision-making }\end{array}$ & \\
\hline & & $\begin{array}{l}\text { CONTINACCESS: Use of Companies House digital services offers the ability to } \\
\text { access financial information on a continuous basis }\end{array}$ & \\
\hline
\end{tabular}

${ }^{a}$ Item marked for deletion 
Appendix C

Discriminant validity: Cross loadings

\begin{tabular}{|c|c|c|c|c|c|c|}
\hline & Compatibility & Complexity & Costs & $\begin{array}{l}\text { Management } \\
\text { support }\end{array}$ & $\begin{array}{l}\text { Technology } \\
\text { competence }\end{array}$ & $\begin{array}{l}\text { Voluntary } \\
\text { adoption of } \\
\text { digital reporting }\end{array}$ \\
\hline ACSSTANDARDS $^{r}$ & 0.939 & -0.145 & -0.066 & 0.219 & 0.106 & 0.134 \\
\hline ITMODIFYING $^{r}$ & 0.680 & -0.148 & -0.171 & 0.197 & 0.011 & 0.063 \\
\hline$E_{F F O R T^{r}}$ & -0.264 & 0.550 & 0.112 & -0.307 & -0.097 & -0.072 \\
\hline BURDEN & -0.030 & 0.836 & -0.052 & 0.013 & 0.159 & -0.109 \\
\hline SETUPCOST $^{r}$ & -0.067 & -0.040 & 0.742 & -0.129 & -0.042 & 0.131 \\
\hline SOFTWARECOST & -0.112 & 0.060 & 0.816 & 0.022 & 0.047 & 0.152 \\
\hline FUNDING & 0.197 & -0.087 & -0.024 & 0.502 & 0.213 & 0.080 \\
\hline CHAMPIONING & 0.219 & -0.150 & -0.061 & 0.969 & 0.282 & 0.278 \\
\hline DIGITALMEDIA & 0.040 & 0.065 & -0.017 & 0.123 & 0.654 & 0.234 \\
\hline E-APPLICATIONS & 0.090 & 0.077 & 0.040 & 0.284 & 0.616 & 0.147 \\
\hline FAMILIARITY & 0.107 & 0.018 & -0.050 & 0.284 & 0.618 & 0.123 \\
\hline TRAINING & 0.000 & 0.022 & 0.047 & 0.123 & 0.539 & 0.158 \\
\hline ANNURET & 0.116 & -0.077 & 0.119 & 0.200 & 0.190 & 0.862 \\
\hline STATACS & 0.113 & -0.131 & 0.075 & 0.201 & 0.220 & 0.675 \\
\hline
\end{tabular}

Note: Bold numbers represent loadings of indicators on the underlying constructs 